\title{
Review \\ The Role of the Gut Microbiome in Diabetes and Obesity-Related Kidney Disease
}

\author{
Amgad Zaky ${ }^{1}$, Sarah J. Glastras ${ }^{1,2}{ }^{(}$, May Y. W. Wong ${ }^{1,2}$, Carol A. Pollock ${ }^{1,2}$ and Sonia Saad ${ }^{1, *}$ \\ 1 Renal Research Laboratory, Kolling Institute of Medical Research, University of Sydney, \\ Sydney, NSW 2065, Australia; amgad.zaky@sydney.edu.au (A.Z.); sarah.glastras@sydney.edu.au (S.J.G.); \\ wong.may.yw@gmail.com (M.Y.W.W.); carol.pollock@sydney.edu.au (C.A.P.) \\ 2 Royal North Shore Hospital, St. Leonards, NSW 2065, Australia \\ * Correspondence: sonia.saad@sydney.edu.au
}

check for updates

Citation: Zaky, A.; Glastras, S.J.; Wong, M.Y.W.; Pollock, C.A.; Saad, S. The Role of the Gut Microbiome in Diabetes and Obesity-Related Kidney Disease. Int. J. Mol. Sci. 2021, 22, 9641 . https://doi.org/10.3390/ ijms22179641

Academic Editor: Deanne H. Hryciw

Received: 13 August 2021

Accepted: 3 September 2021

Published: 6 September 2021

Publisher's Note: MDPI stays neutral with regard to jurisdictional claims in published maps and institutional affiliations.

Copyright: (c) 2021 by the authors. Licensee MDPI, Basel, Switzerland. This article is an open access article distributed under the terms and conditions of the Creative Commons Attribution (CC BY) license (https:/ / creativecommons.org/licenses/by/ $4.0 /)$.

\begin{abstract}
Diabetic kidney disease (DKD) is a progressive disorder, which is increasing globally in prevalence due to the increased incidence of obesity and diabetes mellitus. Despite optimal clinical management, a significant number of patients with diabetes develop DKD. Hence, hitherto unrecognized factors are likely to be involved in the initiation and progression of DKD. An extensive number of studies have demonstrated the role of microbiota in health and disease. Dysregulation in the microbiota resulting in a deficiency of short chain fatty acids (SCFAs) such as propionate, acetate, and butyrate, by-products of healthy gut microbiota metabolism, have been demonstrated in obesity, type 1 and type 2 diabetes. However, it is not clear to date whether such changes in the microbiota are causative or merely associated with the diseases. It is also not clear which microbiota have protective effects on humans. Few studies have investigated the centrality of reduced SCFA in DKD development and progression or the potential therapeutic effects of supplemental SCFAs on insulin resistance, inflammation, and metabolic changes. SCFA receptors are expressed in the kidneys, and emerging data have demonstrated that intestinal dysbiosis activates the renal renin-angiotensin system, which contributes to the development of DKD. In this review, we will summarize the complex relationship between the gut microbiota and the kidney, examine the evidence for the role of gut dysbiosis in diabetes and obesity-related kidney disease, and explore the mechanisms involved. In addition, we will describe the role of potential therapies that modulate the gut microbiota to prevent or reduce kidney disease progression.
\end{abstract}

Keywords: microbiota; diabetes; obesity; kidney disease

\section{Introduction}

Diabetic kidney disease (DKD) is a devastating complication of both type 1 and type 2 diabetes mellitus (T1D and T2D), predicted to affect around 40\% of patients with diabetes by 2045 [1,2]. DKD significantly increases the risk of developing cardiovascular disease and end-stage kidney disease (ESKD), which ultimately necessitates dialysis or kidney transplantation $[3,4]$. The global incidence of ESKD continues to increase by $6-12 \%$ annually, driven by the increasing prevalence of obesity and T2D [5].

The microbiome has 150 times more genes than the human genome [6]. The microbiota is established from birth and shaped during the first three years of life $[7,8]$. Gender, age, family history, ethnicity, dietary preference, geographical areas of living, use of probiotics, prebiotics, and antibiotics, are all factors which influence the gut microbiota composition [9-11]. The gut microbiota is important in maintaining the gastrointestinal and immune functions through the digestion and fermentation of nutrients as well as electrolyte and mineral absorption $[9,12]$. It collects signals from the surrounding environment and nutrients to produce metabolites working symbiotically with the immune system. Such signals boost the defense against different pathogens resulting in health promotion $[13,14]$. 
The gut microbiota plays an important role in physiology and disease state, including obesity, diabetes, asthma, allergy, cancer, cardiovascular disease, and aging, and more recently, gut dysbiosis has been implicated in DKD [15-19]. Diabetes and obesity, which are common in patients with $\mathrm{T} 2 \mathrm{D}$, are associated with alterations in the gut microbiota, and recent studies suggest that DKD initiation and progression are associated with an altered gut microbial ecology or dysbiosis [20,21]. This review will summarise the evidence for the role of gut dysbiosis in diabetes, obesity, and DKD, raising the possibility that the gut microbiota may be a potential target to prevent and reduce the progression of DKD.

\section{Gut Microbiota Community}

The gut microbiota is a dynamic community of microorganisms made up of 100 trillion microbes living within the gastrointestinal system of the host organism. Bacteria make up the majority of the microorganisms, though viruses and fungi also contribute $[15,22]$, accounting for 1.5 to $2 \mathrm{~kg}$ of human body weight $[9,23]$. Six phyla are dominant in the gut microbiota, including Fusobacteria, Firmicutes, Proteobacteria, Verrucomicrobia, Actinobacteria, and Bacteroidetes, with Firmicutes and Bacteroidetes representing around 90\% of the gut microbiota [24,25].

Fusobacterium are generally considered pathogenic since Fusobacterium strains cause several human diseases. Firmicutes and proteobacteria are also considered harmful bacteria due to their negative influence on glucose and fat metabolism. However, Verrucomicrobia, actinobacteria, and Bacteroidetes are considered 'good' bacteria due to their contribution to intestinal health and glucose homeostasis [26], host resistance to infective disease [27], and the production of favorable metabolites such as short-chain fatty acids (SCFAs), known to reduce inflammation [28].

The Bacteroidetes and Firmicutes phyla normally contribute the most to gut microbiota [29]. Bacteroides and Prevotella are the two dominant genera of the Bacteroidetes phylum, while Clostridium, Ruminococcus, Bacillus, Lactobacillus, and Enterococcus, alongside 200 other genera, form the phylum of Firmicutes [25]. The Clostridia class of the Clostridium genus forms $95 \%$ of the Firmicutes phylum [29].

\section{Gut Microbiota By-Products and Functions}

\subsection{Short Chain Fatty Acids-The By-Products of Microbial Metabolism}

Polysaccharide fermentation, induced by gut microbiota, produces short chain fatty acids (SCFA), which are utilized by colon epithelial cells as nutrition. Propionate, acetate, and butyrate are the main SCFAs produced by the bacterial fermentation of dietary fiber in the gut [30]. SCFAs provide around 6-10\% of the body's total daily energy [31,32]. The majority of SCFAs are absorbed in the colon (90-95\%), while the rest (5-10\%) are secreted within the stool. About $60 \%$ of SCFA absorption takes place via epithelial membrane diffusion, whilst the remainder is absorbed by active cell transportation, specifically monocarboxylate transporters in colonocytes $[33,34]$. Those which are not metabolized by colonocytes (mainly butyric acid) are transported through the portal circulation and metabolized in the liver before they reach the systemic circulation. However, the distal colon, where most of the gut microbiota reside, bypasses the portal circulation, allowing systemic access $[30,35]$. Hence, SCFAs produced by the microbiota can be present in portal, hepatic, peripheral blood, and feces [35-37]. Low levels of SCFAs in the blood and gastrointestinal system are implicated in diabetes and inflammatory disease [38,39].

\subsection{Short Chain Fatty Acid Interaction with End-Organ Receptors}

The SCFAs produced by the gut microbiota are absorbed into the bloodstream and reach distant tissues such as the liver, adipose tissue, and kidneys after their uptake by $G$ protein-coupled receptors (GPRs), including GPR41, GPR43, GPR109A, and Olf78. SCFAs differentially activate GPRs; propionate activates GPR41 and GPR43, acetate activates GPR43, and butyrate activates GPR41 [40] (Figure 1). Through the activation of GPR41 and 43 within adipocytes, epithelial and mononuclear cells, SCFAs initiate adipogenesis, 
suppress the synthesis of cholesterol and fatty acids in the liver, and regulate obesity in mice [30,41]. In addition, GPR-41 activation improves blood pressure regulation, whereas GPR-43 activation enhances cell immune responses [38].

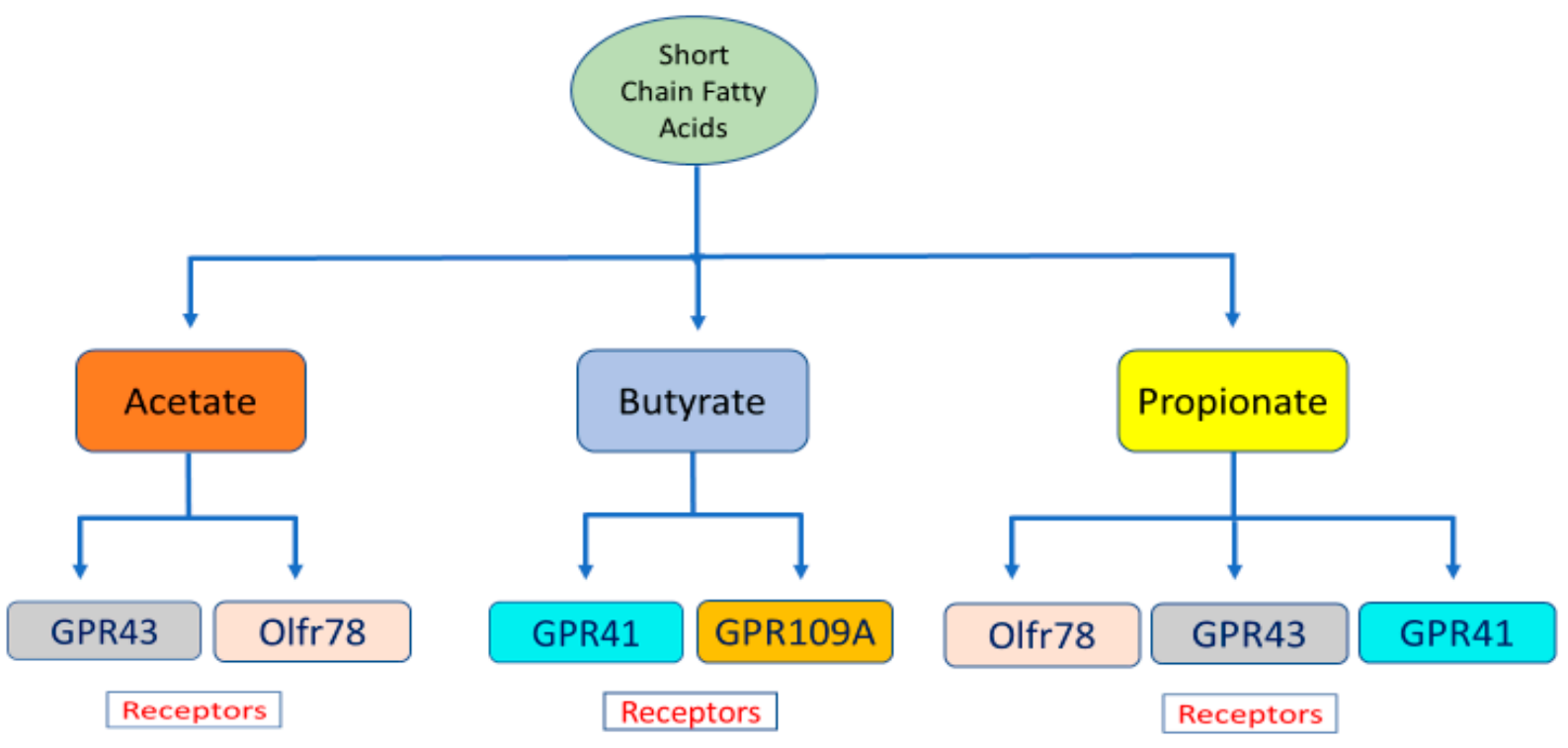

Figure 1. SCFA receptors and their relationship with different types of SCFAs.

GPR-109A may have an additional role in limiting inflammation [42]. Animal and human studies have demonstrated an association between GPR109A expression and colon cancer, suggesting it may be a tumor suppressor $[38,43,44]$. GPR109A activated by SCFAs also inhibits NF-kB activation and pancreatic beta cells inflammation in mice [44].

Unlike the other receptors, the Olfr-78 receptor does not respond to butyrate but is more sensitive to propionate and acetate [45]. In addition to its role in olfaction and hormone regulation, Olfr-78 acts as a hypoxia sensor and plays a role in renin secretion and blood pressure regulation [46-48].

Olfr-78, GPR-43, GPR-41, and GPR-109A are all expressed in the kidney [46,49,50], such that SCFAs can influence kidney health. Olfr-78 is expressed in the renal juxtaglomerular apparatus and smooth muscle cells of small resistance vessels [46]; its human orthologue (hOR51E2) is expressed in the human kidney, as well as in multiple other tissues such as heart and skeletal muscle [49]. GPR-43 is expressed in human embryonic kidney cells [50]. GPR-41 is also expressed in renal arteries and smooth muscle cells, suggesting that the biological role of these receptors possibly extends beyond their role in regulating the release of peptide hormone from enteroendocrine cells in the gut to include modulation of kidney health [51]. Finally, increased expression of GPR109A in podocytes shows a protective effect against proteinuria in an animal model of renal injury by stabilizing glomerular basement membrane podocytes and attenuating glomerulosclerosis and renal inflammation [52]. Hence, SCFAs produced by the gut microbiota have a potential role in kidney health and disease.

Multiple studies have demonstrated the role of SCFAs in gene regulation of antiinflammatory processes both in vitro and in vivo [53]. SCFAs are implicated in energy metabolism and are known to affect lipid, glucose, and cholesterol metabolism and improve insulin sensitivity; thus, supporting the role of microbiota in glycemic control $[54,55]$. The effect of SCFAs on gene transcription can occur via epigenetic regulation-heritable phenotype changes that do not involve alterations in the DNA sequence [56,57]. In intestinal epithelial cells, propionate and butyrate have been shown to inhibit the activity of histone deacetylase enzymes (HDAC 3 and HDAC1), which in turn increase histone acetylation. The inhibition of HDACs by SCFAs can decrease histone compactness, NF- $\mathrm{kB}$ (nuclear factor $\mathrm{kB}$ ) and myogenic antigen differentiation, colonocyte P53 expression, and nuclear 
factor of activated T cell (NFAT) production [38,58,59]. Microbiota-derived SCFAs were recently shown to promote the post-translational modification of histones in the colon through histone deacetylation. Epigenetic modifications due to SCFAs have also been implicated in the development of diabetes and chronic kidney disease $[60,61]$.

\section{Dysbiosis in Diabetes, Obesity, and Chronic Kidney Disease}

\subsection{Role of the Gut Microbiota in Type 1 Diabetes}

The incidence of T1D has steeply risen in recent decades in both developed and developing countries; genetic factors are inadequate to explain the increased incidence, leading to investigators searching for alternate explanations.

T1D is an autoimmune disease. It is known that lipopolysaccharide (LPS) plays a significant role in increasing the level of pro-inflammatory cytokines via toll-like receptors (TLRs) [62-64], thereby playing a possible role in causing pancreatic beta-cell failure in susceptible individuals. LPS is a major component of the outer membrane of Gramnegative bacterial species, and LPS can be derived from microbiota in the gut $[62,65]$. A direct causal relationship between gut dysbiosis and the development of T1D is yet to be established. However, mounting evidence strongly suggests a link. There is increasing evidence to suggest that the gut microbiota plays an integral role in this altered trajectory from early life in both animal and human studies (Tables 1 and 2, respectively). Multiple studies have demonstrated that patients with T1D have distinctly different gut microbiota, in comparison with healthy subjects, characterized by a decreased Firmicutes (Grampositive): Bacteroidetes (Gram-negative) ratio [66-70]. Bacteroides were more prevalent in patients with T1D in association with an increase in inflammatory cytokine, interleukin (IL)-6, and poor glycemic control [71]. Bacteroides ovatus encompassed around $24 \%$ of the total increase in the phylum Bacteroidetes [70]. A higher amount of Bacteroidetes in patients with T1D correlated with increased toll-like receptor (TLR)-4, TLR-2 levels [66], and anti-islet cell autoantibodies [67]. Faecalibacterium levels are also negatively correlated with glycated hemoglobin (HbA1c) [67]. In addition, increased Bacteroidetes and lower levels of Faecalibacterium were also demonstrated in patients with MODY2 (maturity-onset diabetes of the young 2) [72]. It is worth noting that Pellegrini et al. showed an increased Firmicutes: Bacteroidetes ratio in a small cohort of patients with T1D compared to the control [73]. The increase in Firmicutes was mostly related to the abundant levels of Bacilli class and Streptococcus genus. It is not clear whether this discrepancy is due to geographical differences, small sample sizes, or the analytic data techniques used.

Table 1. Animal studies of the gut microbiota in T1D.

\begin{tabular}{|c|c|c|c|c|}
\hline Reference & Authors & Year of Study & Animal Model & Study Findings \\
\hline$[74]$ & Wu et al. & 2021 & $\begin{array}{l}\text { NOD/lij T1D mice } \\
\text { vs. ICR mice }\end{array}$ & $\begin{array}{l}\text { Decreased microbiota diversity and community } \\
\text { richness were shown in animals before the onset } \\
\text { of T1D. } \\
\text { T1D was associated with increased Firmicutes, } \\
\text { Proteobacteria, and Deferribacteres phyla abun- } \\
\text { dance. } \\
\text { Coprococcus 2, Lachnoclostridium_5, and Lach- } \\
\text { nospariceae_FCS020 genera (Firmicutes Phylum) } \\
\text { were dominant in T1D, and their levels posi- } \\
\text { tively correlated with blood neutrophil ratios. }\end{array}$ \\
\hline
\end{tabular}


Table 1. Cont.

\begin{tabular}{|c|c|c|c|c|}
\hline Reference & Authors & Year of Study & Animal Model & Study Findings \\
\hline [75] & Ma et al. & 2020 & $\begin{array}{l}\text { Streptozotocin- } \\
\text { induced T1D rats vs. } \\
\text { control }\end{array}$ & $\begin{array}{l}\text { - Firmicutes and Bacteroidetes are the dominant } \\
\text { phyla in T1D rats. } \\
\text { Pathogenic bacteria are abundant in T1D rats, } \\
\text { while beneficial bacteria are reduced compared } \\
\text { to control. } \\
\text { Butyricicoccus and Allobaculum produce SCFAs } \\
\text { and protect intestinal barrier function. } \\
\text { Imbalance of gut microbiota causes reduction of } \\
\text { SCFAs and intestinal inflammation. }\end{array}$ \\
\hline [76] & Prasad et al. & 2019 & $\begin{array}{l}\text { Angiotensin- } \\
\text { converting enzyme } 2 \\
\text { (ACE2) deficient T1D } \\
\text { Akita mice vs. control }\end{array}$ & $\begin{array}{l}\text { - Increased Firmicutes and Bacteroidetes in the } \\
\text { gut of ACE2 }{ }^{-/-} \text {Akita mice } \\
\text { - } \quad \text { ACE2 loss induced gut barrier permeability. } \\
\text { Dysbiosis in the gut promoted the development } \\
\text { of diabetic nephropathy. }\end{array}$ \\
\hline [77] & Patterson et al. & 2015 & $\begin{array}{l}\text { Streptozotocin (STZ) } \\
\text { induced T1D in } \\
\text { Sprague-Dawley rats } \\
\text { (over time) vs. control }\end{array}$ & $\begin{array}{l}\text { - Animals with T1D have decreased microbial di- } \\
\text { versity and differential expression of microbiota. } \\
\text { T1D onset was associated with an increase in } \\
\text { Bacteriodetes: Firmicutes ratio. } \\
\text { Increased lactic acid-producing bacteria (Bifi- } \\
\text { dobacterium and Lactobacillus) was associated } \\
\text { with late-stage T1D progression. }\end{array}$ \\
\hline [78] & Hara et al. & 2012 & $\begin{array}{l}\text { Virus-induced T1D rats } \\
\text { vs. control }\end{array}$ & $\begin{array}{l}\text { Virus-induced T1D animals expressed increased } \\
\text { levels of Bifibacterium and Clostridium species } \\
\text { and were reduced following antibiotic adminis- } \\
\text { tration. }\end{array}$ \\
\hline [79] & Roesch et al. & 2009 & $\begin{array}{l}\text { Bio-breeding } \\
\text { diabetes-prone (BB-DP) } \\
\text { vs. bio-breeding } \\
\text { diabetes-resistant } \\
\text { (BB-DR) rats }\end{array}$ & $\begin{array}{l}\text { BB-DR rats had more Lactobacillus and Bifidobac- } \\
\text { terium genera vs. BB-DP. } \\
\text { Increased levels of } 9 \text { genera were also demon- } \\
\text { strated in BB-DP rats in correlation with the on- } \\
\text { set of diabetes. }\end{array}$ \\
\hline [80] & Brugman et al. & 2006 & $\begin{array}{l}\text { Diabetic BB-DP rats } \\
\text { before and after the } \\
\text { onset of diabetes in the } \\
\text { presence and absence } \\
\text { of antibiotics }\end{array}$ & $\begin{array}{l}\text { Rats protected from diabetes had a lower } \\
\text { amount of Bacteroides species compared to rats } \\
\text { with high levels. } \\
\text { Modulation of microbiota by antibiotics reduced } \\
\text { the incidence of T1D and delayed its onset. }\end{array}$ \\
\hline
\end{tabular}

Table 2. Human studies of the gut microbiota in T1D.

\begin{tabular}{ccccc}
\hline Reference & Authors & Year of Study & $\begin{array}{c}\text { Number of Study } \\
\text { Participants }\end{array}$ & Study Findings \\
\hline [66] & Demirci et al. & 2020 & $\begin{array}{c}53 \text { T1D vs. 53 healthy } \\
\text { participants (Turkish } \\
\text { population) }\end{array}$ & $\begin{array}{l}\text { Firmicutes: Bacteroidetes ratio was decreased in } \\
\text { T1D vs. healthy control. This correlated with TLR4 } \\
\text { and TLR2 levels. }\end{array}$ \\
\hline
\end{tabular}


Table 2. Cont.

\begin{tabular}{|c|c|c|c|c|}
\hline Reference & Authors & Year of Study & $\begin{array}{l}\text { Number of Study } \\
\text { Participants }\end{array}$ & Study Findings \\
\hline [67] & Huang et al. & 2018 & 12 T1D vs. 10 healthy & $\begin{array}{l}\text { - T1D patients were characterized by decreased Fir- } \\
\text { micutes: Bacteroidetes ratios. } \\
\text { - HbA1c negatively correlated with Faecalibacterium } \\
\text { levels. } \\
\text { There was a positive correlation between Bac- } \\
\text { teroides levels and the presence of anti-islet cell } \\
\text { autoantibodies. }\end{array}$ \\
\hline
\end{tabular}

[81] Gürsoy et al. $2018 \quad \begin{aligned} & \text { 42 newly diagnosed } \\ & \text { T1D vs. } 42 \text { healthy }\end{aligned}$

- Increased levels of intestinal Candida albicans species at the time of diagnosis of T1D patients showing that normal intestinal microbiota is impaired.

- $\quad$ Decreased microbial diversity and increased gut permeability in the T1D group compared to other groups.

15 T1D, and 15 maturity-onset

[72] Leiva-Gea et al.

2018 diabetes of the young

2 (MODY2) vs. 13 healthy
- Increased levels of Bacteroides, Veillonella, Ruminococcus, Blautia, and Streptococcus genera and reduced levels of Bifidobacterium, Roseburia, Lachnospira, and Faecalibacterium in the T1D group compared to control and patients with MODY2 (other non-autoimmune diabetes).

[71] Higuchi et al. $2018 \quad \begin{aligned} & 20 \mathrm{~T} 1 \mathrm{D} \text { vs. } 28 \text { healthy } \\ & \text { (Brazilian population) }\end{aligned}$

- Gram-negatives Bacteroides (vulgatus, xylanisolvens, and rodentium) and Prevotella Copri were more prevalent in patients with T1D in association with increased IL-6 and poor glycemic control.

- Firmicutes: Bacteroidetes ratio was increased in the T1D group, while Bacteroidetes and Proteobacteria phyla levels were reduced.

[73] Pellegrini et al. $2017 \quad \begin{aligned} & \text { 19 T1D vs. } 16 \text { healthy } \\ & \text { (Italian population) }\end{aligned}$

Specific correlation was uniquely demonstrated between the microbiota and 7 inflammatory genes expressed in patients with T1D.

- $\quad$ Bacteroides and Clostridium clusters XVa and IV were abundant in children with T1D.

- $\quad$ Bifidobacterium spp. were abundant in the healthy group.

[82] Pinto et al. $2016 \quad \begin{gathered}3 \text { T1D vs. } 3 \text { healthy } \\ \text { children }\end{gathered}$

- Identified 26 more abundant bacterial proteins in T1D and 21 more abundant proteins in healthy children. The specific protein functions of those genes were documented.

- Healthy children > 2.9 years had increased levels of Clostridium clusters IV and XIVa vs. T1D children or children $<2.9$ years of age.

$\begin{array}{ccc}\text { [83] } & 2014 & \text { old) with new-onset } \\ \text { et al. } & \text { T1D vs. 27 healthy }\end{array}$

28 children (1-5 years T1D vs. 27 healthy
- Bacilli class (Streptococci) and Bacteroidetes phylum were higher in T1D children $<2.9$ years vs healthy, whereas healthy children had more levels of butyrate-producing species (Clostridium clusters IV and XIVa). 
Table 2. Cont.

\begin{tabular}{ccccc}
\hline Reference & Authors & Year of Study & $\begin{array}{c}\text { Number of Study } \\
\text { Participants }\end{array}$ & Study Findings \\
\hline [84] & Soyucen et al. & \multirow{2}{*}{2014} & $\begin{array}{c}35 \text { newly diagnosed } \\
\text { T1D vs. 35 healthy }\end{array}$ & $\begin{array}{l}\text { Reduction in the levels of beneficial anaerobic bac- } \\
\text { teria (Bifidobacterium genus) and increased Can- } \\
\text { dida albicans and Enterobacteriaceae (other than Es- } \\
\text { cherichia coli) species were demonstrated in newly } \\
\text { diagnosed T1D vs. control. }\end{array}$ \\
\end{tabular}

- T1Ds had significant decrease in the ratio of Firmicutes: Bacteroidetes and reduced levels of the Blautia coccoides-Eubacterium rectal group (involved in butyrate production and maintenance of gut integrity).

[68] Murri et al. $2013 \quad \begin{gathered}16 \text { children with T1D } \\ \text { vs. } 16 \text { healthy }\end{gathered}$

- Increased Clostridium, Bacteroides, and Veillonella genera and reduced Lactobacillus, Prevotella, and Bifidobacterium genera were also demonstrated in children with T1D.

- $\quad$ Firmicutes declined, and Bacteroidetes increased in the gut microbiota as children develop T1D.

- $\quad$ Reduced bacterial diversity was shown over time in autoimmune individuals.

[70] Giongo et al.

2011

4 children with T1D autoimmunity vs. 4 healthy
- Autoimmune microbiota instability and the high ratio of Firmicutes: Bacteroidetes within the first 6 months after birth may be an indication of the future development of autoimmunity; before the detection of serum antibodies and might have potential in early diagnosis.

- Firmicutes: Bacteroidetes ratio was reduced in autoimmune vs. healthy children.

- Lactate-producing bacteria (Lactobacillus, Lactococcus, Streptococcus, and Bifidobacterium) were less abundant in autoimmunity vs. control.

[69] Brown et al.

2011
4 children with $\beta$-cell autoimmunity vs. 4 healthy
Increased butyrate-producing bacteria (e.g., Eubacterium, Subdoligranulum, Fusobacterium, Roseburia, Anaerostipes, and Faecalibacterium) and mucindegrading bacteria (Prevotella and Akkermansia) were shown in control vs. autoimmunity.

Animal and human studies demonstrated reduced bacterial diversity and stability over time in autoimmune individuals and in patients with T1D [70,72,77]. However, children who will develop autoimmunity have a microbiota that is less diverse and stable [70]. Reduction in the levels of beneficial anaerobic bacteria (Bifidobacterium genus) and an increase in the levels of Candida albicans and Enterobacteriaceae (other than Escherichia coli) species were demonstrated in newly diagnosed T1D vs. control [84]. Patterson et al. demonstrated that T1D-onset was associated with an increase in the Bacteroidetes: Firmicutes ratio [77]. Rats that were protected from diabetes had a lower amount of Bacteroides [80] and modulation of microbiota by antibiotics was able to reduce the incidence of T1D and delay its onset [80].

Children with T1D had reduced levels of Blautia coccoides-Eubacterium rectal group (involved in butyrate production and maintenance of gut integrity), whereas healthy children had more levels of butyrate-producing species such as Clostridium clusters IV and XIVa compared to children with T1D [83]. Increased Clostridium, Bacteroides, and Veillonella genera and reduced Lactobacillus, Prevotella, and Bifidobacterium genera were also 
demonstrated in children with T1D [68]. Some studies demonstrated that alterations in the gut microbiota might precede the development of T1D [[69,70,74,80]. Indeed, Firmicutes declined, and Bacteroidetes increased in the gut microbiota as children develop T1D, and hence a lower ratio of Firmicutes: Bacteroidetes level was detected in normal children compared to children who become autoimmune [70]. Brown et al. demonstrated that the lactate-producing bacteria (Lactobacillus, Lactococcus, Streptococcus, and Bifidobacterium) were less abundant in autoimmunity. Interestingly, increased Lactobacillus and Bifidobacterium were associated with late-stage T1D progression [77]. Increased butyrate-producing bacteria and mucin-degrading bacteria were shown in the control compared to autoimmune groups. The reduction of mucin-producing bacteria in autoimmunity can contribute to the gut immune imbalance and reduction of gut integrity in the population. Autoimmune microbiota instability and alteration in the ratio of Firmicutes: Bacteroidetes within the first 6 months after birth may be an indication of future development of autoimmunity, before the detection of serum antibodies, and has potential for early diagnoses.

\subsection{Role of the Gut Microbiota in Type 2 Diabetes}

Compared with the available evidence in T1D, there is less information about the role of the gut microbiota and the development and progression of T2D (Tables 3 and 4).

Table 3. Animal studies of the gut microbiota in T2D.

\begin{tabular}{|c|c|c|c|c|}
\hline Reference & Authors & Year of Study & Subjects Number & Study Findings (Microbiota Changes in T2D vs. Control) \\
\hline [85] & Kesh et al. & 2020 & $\begin{array}{l}\text { T2D mice vs. control (both } \\
\text { with pancreatic } \\
\text { adenocarcinoma }+/- \\
\text { chemotherapy) }\end{array}$ & $\begin{array}{l}\text { - Bacteroides intestinalis and Lactobacillus murinus species } \\
\text { were more abundant in the control group. } \\
\text { Enterobacter cloacae and Bacteroides uniformis species were } \\
\text { specifically expressed in the T2D group. } \\
\text { Dysbiosis in the microbiota seen in animals with T2D } \\
\text { associated with increased resistance to chemotherapy. }\end{array}$ \\
\hline [86] & Yin et al. & 2020 & $\begin{array}{l}\text { T2D mice (induced by } \\
\text { high-fat or } \\
\text { high-sucrose-fat diet + } \\
\text { STZ) } \\
\text { vs. control }\end{array}$ & $\begin{array}{l}\text { - Bacteroidetes levels were reduced in high-fat diet-fed } \\
\text { mice vs. high sucrose. } \\
\text { Intestinal microbiota composition did not change after } \\
\text { STZ, suggesting that the difference in metabolic pheno- } \\
\text { types and gut microbiota was diet-related. }\end{array}$ \\
\hline [87] & Grasset et al. & 2017 & $\begin{array}{l}\text { T2D obese mice (fed HFD/ } \\
\text { high-carbohydrate diet) } \\
\text { and T2D mice (fed } \\
\text { HFD/carbohydrate-free } \\
\text { diet) compared to control } \\
\text { (on chow diet) }\end{array}$ & 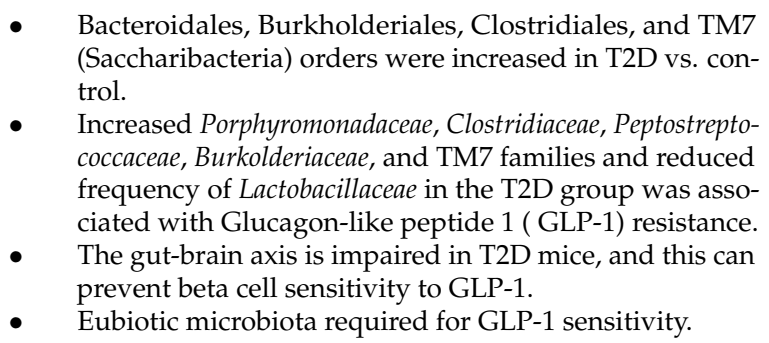 \\
\hline [88] & Everard et al. & 2013 & $\begin{array}{l}\mathrm{ob} / \mathrm{ob} \text { mice and HFD-fed } \\
\text { mice, with and without } \\
\text { prebiotics vs. lean control } \\
\text { mice }\end{array}$ & $\begin{array}{l}\text { - The presence of Bacterium inversely correlated with } \\
\text { body weight. } \\
\text { - Akkermansia }(A) \text { muciniphila is reduced in obese mice and } \\
\text { mice with T2D. } \\
\text { - A. muciniphila administration reversed obesity-related } \\
\text { metabolic disease, increased the levels of endocannabi- } \\
\text { noids, and controlled inflammation. }\end{array}$ \\
\hline
\end{tabular}


Table 4. Human studies of the gut microbiota in T2D.

\begin{tabular}{|c|c|c|c|c|}
\hline Reference & Authors & $\begin{array}{l}\text { Year of } \\
\text { Study }\end{array}$ & Subjects Number & $\begin{array}{c}\text { Study Findings (Microbiota Changes in T2D vs. } \\
\text { Control) }\end{array}$ \\
\hline [89] & Li et al. & 2020 & $\begin{array}{l}20 \text { T2D patients vs. } 40 \\
\text { healthy individuals from } \\
\text { North China }\end{array}$ & $\begin{array}{l}\text { - Decreased gut microbe diversity. } \\
\text { T2D had reduced levels of Butyrate-producing } \\
\text { bacteria (Bifidobacterium, Akkermansia, Faecal- } \\
\text { ibacterium) and increased levels of bacteria in- } \\
\text { volved in chronic inflammation (Dorea). } \\
\text { - Abundance in Dorea's levels could identify pa- } \\
\text { tients at high risk for T2D. }\end{array}$ \\
\hline [90] & $\begin{array}{l}\text { Chávez- } \\
\text { Carbajal } \\
\text { et al. }\end{array}$ & 2020 & $\begin{array}{l}217 \text { pre-diabetic and } \\
\text { diabetic patients with and } \\
\text { without treatment vs. } \\
\text { healthy individuals } \\
\text { (Mexican subjects) }\end{array}$ & $\begin{array}{l}\text { - } \quad \text { Reduced bacterial richness and diversity. } \\
\text { Pre-diabetic and diabetic groups had specific } \\
\text { predicted metabolic characteristics and gut } \\
\text { bacteria. }\end{array}$ \\
\hline [91] & Doumatey et al. & 2020 & $\begin{array}{l}98 \text { T2D Nigerians vs. } \\
193 \text { healthy Nigerians }\end{array}$ & $\begin{array}{l}\text { - Increased Actinobacteria and Bacteroidetes } \\
\text { phyla. } \\
\text { - } \quad \text { Decreased Firmicutes phylum. } \\
\text { - } \quad \text { Clostridiaceae and Peptostreptococcaceaea } \\
\text { - } \quad \text { families were significantly reduced. }\end{array}$ \\
\hline [92] & Sedighi et al. & 2017 & 18 T2D vs. 18 healthy & $\begin{array}{l}\text { - Bifidobacterium genus was reduced while Lacto- } \\
\text { bacillus was significantly increased. }\end{array}$ \\
\hline [93] & Inoue et al. & 2017 & $\begin{array}{l}12 \text { T2D vs. } 10 \text { healthy } \\
\text { (Japanese population) }\end{array}$ & $\begin{array}{l}11 \text { pathways were significantly enriched in } \\
\text { the diabetic group, including insulin signal- } \\
\text { ing, glycolysis, and glycogenesis pathways. } \\
\text { Significant reduction in Blautia genus, nega- } \\
\text { tively correlated with HbA1c and glucose lev- } \\
\text { els. }\end{array}$ \\
\hline [94] & Wu et al. & 2010 & 16 T2D vs. 12 healthy & $\begin{array}{l}\text { - Reduction in species profiles and reduced lev- } \\
\text { els of Bifidobacterium genus and Bacteroides vul- } \\
\text { gatus. }\end{array}$ \\
\hline [95] & Larsen et al. & 2010 & 18 T2D vs. 18 healthy & $\begin{array}{l}\text { Bacteroidetes: Firmicutes ratio and Bacteroides- } \\
\text { Prevotella to Blautia coccoides -Eubacterium rectal } \\
\text { correlated positively with plasma glucose lev- } \\
\text { els. }\end{array}$ \\
\hline [96] & Bilen et al. & 2007 & 66 T2D vs. 50 healthy & $\begin{array}{l}\text { - Conjunctival flora from patients with T2D had } \\
\text { increased Staphylococcus aureus and Staphylo- } \\
\text { coccus epidermidis compared to control. }\end{array}$ \\
\hline
\end{tabular}

Recent animal studies suggest a relationship between gut dysbiosis and insulin resistance that underpins T2D [97], involving mechanisms that include increased endotoxemia, bowel permeability changes, bile acids interaction, and changes in brown fat distribution [9]. Modification of the gut microbiota by probiotics and/or prebiotics appears to promote glucose homeostasis and improved insulin resistance [97]. Dao et al. showed the gut profusion of Akkermansia muciniphila bacteria is directly associated with improvements in glucose homeostasis in humans with early T2D [98].

Moroti et al. demonstrated that administration of symbiotic shakes containing Bifidobacterium bifidum and lactobacillus acidophilus to patients with T2D decreased fasting blood glucose levels [99]. Alterations of the gut microbiota composition to that resembling the 
healthy controls had a positive impact on T2D-associated diseases, such as diabetic foot ulcers and diabetic retinopathy $[100,101]$.

Overall, as in T1D, a decrease in gut microbe diversity and richness was demonstrated in patients with type 2 diabetes compared to healthy controls $[89,90]$. Pre-diabetic and diabetic groups had specific metabolic characteristics and gut bacteria [90]. Patients with T2D had reduced levels of Butyrate-producing bacteria such as Bifidobacterium, Akkermansia, and Faecalibacterium $[89,92,94]$ and reduced levels of the Firmicutes phylum, and Clostridiaceae and Peptostreptococcaceaea families compared to healthy controls [91]. Significant reduction in the Blautia genus was also demonstrated in patients with T2D and this negatively correlated with HbA1c and glucose levels [93]. Using an animal model of T2D, Everard et al. demonstrated that Akkermansia (A) muciniphila is reduced in mice with T2D, and administration of $A$. muciniphila increased the levels of endocannabinoids and controlled inflammation [88].

Increased Bacteroidetes and decreased Firmicutes levels were demonstrated at the onset of T2D [90]. Patients with T2D also had increased levels of Actinobacteria and Bacteroidetes phyla [91] and Lactobacillus [92,94]. Reduced frequency of Lactobacillaceae in the T2D group is associated with GLP-1 resistance [87]. Hence, Alterations in the microbiota levels can improve GLP-1-based therapies. The Bacteroidetes to Firmicutes ratio and Bacteroides-Prevotella to Blautia coccoides -Eubacterium rectal were also increased in patients with T2D, and this was shown to positively correlate with plasma glucose levels [95]. The levels of Clostridia in the stool were decreased in patients with T2D [95]. It is interesting to note that the reduced levels of Bifidobacteria and Firmicutes: Bacteroidetes ratio were similarly observed in patients with T1D. Human studies have also demonstrated that patients with T2D have increased levels of Dora genus (from the family Lachnospiraceae), which is known to be involved in chronic inflammation, and it is proposed that such levels could identify patients at high risk of T2D [89]. Collectively, these studies demonstrated an important role of the microbiota on T2D development. In addition, Bilen et al. demonstrated that Staphylococcus aureus and Staphylococcus epidermidis were increased in conjunctival flora from patients with T2D compared to control [96]. Dysbiosis in the microbiota seen in animals with T2D was associated with increased resistance to chemotherapy [85].

\section{Role of the Gut Microbiota in Obesity}

There is a bidirectional relationship between gut dysbiosis and obesity. Imbalanced gut microbiota is linked to the development of obesity through the modulation of energy homeostasis, autonomous contribution to fat accumulation, and decreased activity of lipoprotein lipase enzyme [9]. Feeding germ-free rodents a high-fat diet (HFD) to induce obesity produces changes in the gut microbiota, such as increased Firmicutes and Proteobacteria bacteria together with decreased Bacteroidetes bacteria [102]. Animals and human studies support the role of the gut microbiota in obesity (Tables 5 and 6).

Table 5. Animal studies of the gut microbiota in obesity.

\begin{tabular}{|c|c|c|c|c|}
\hline Reference & Authors & $\begin{array}{l}\text { Year of } \\
\text { Study }\end{array}$ & Animal Model & $\begin{array}{c}\text { Study Findings (Microbiota Changes in Obesity vs. } \\
\text { Control) }\end{array}$ \\
\hline [103] & Sang et al. & 2021 & $\begin{array}{l}\text { Obese (HFD-fed mice) } \\
\text { with and without } \\
\text { Ganoderma lucidum vs. } \\
\text { control (low-fat diet) }\end{array}$ & $\begin{array}{l}\text { - Obese (HFD-fed mice) had increased Firmicutes: } \\
\text { Bacteroidetes ratio in the gut microbiota vs. con- } \\
\text { trol. } \\
\text { - Reduced Bifidobacterium choerinum and Bacteroide } \\
\text { chinchillae levels. } \\
\text { Ganoderma lucidum treatment increased Allobacul- } \\
\text { lum, Christensenella, and Bifidobacterium and inhib- } \\
\text { ited body weight increase and inflammation due } \\
\text { to HFD in association with increased SCFAs levels } \\
\text { and GPR43 activation. }\end{array}$ \\
\hline
\end{tabular}


Table 5. Cont.

\begin{tabular}{cccc}
\hline Reference & Authors & $\begin{array}{c}\text { Year of } \\
\text { Study }\end{array}$ & Animal Model \\
\hline & & \\
{$[104]$} & Beckmann et al. & 2021 & $\begin{array}{l}\text { Diet-induced obesity in } \\
\text { rats (with and without } \\
\text { telmisartan) vs. control }\end{array}$
\end{tabular}

Study Findings (Microbiota Changes in Obesity vs. Control)

- Increased Firmicutes: Bacteroidetes ratio in diet-induced obesity vs. control.

- Increased Blautia, Allobaculum, and Parasutterella levels.

- Transfer of stool from telmisartan-treated mice to obese mice attenuated the increase in body weight due to dietary-induced obesity.

\begin{tabular}{|c|c|c|c|c|}
\hline [105] & Bagarolli et al. & 2017 & $\begin{array}{l}\text { HFD-fed mice with and } \\
\text { without probiotics vs. } \\
\text { control }\end{array}$ & $\begin{array}{l}\text { - HFD increased Bacteroidetes and decreased } \\
\text { the levels of Firmicutes and Actinobacteria } \\
\text { phyla. } \\
\text { - } \quad \text { HFD increased intestinal permeability. } \\
\text { Probiotics reduced fat pad and weight gain } \\
\text { and improved insulin resistance and glucose } \\
\text { tolerance. }\end{array}$ \\
\hline [106] & Lam et al. & 2012 & $\begin{array}{l}\text { Obese (HFD-fed mice) vs. } \\
\text { control (chow diet-fed } \\
\text { mice) }\end{array}$ & $\begin{array}{l}\text { - Reduced Lactobacillus genus leading to in- } \\
\text { creased inflammatory cytokines. } \\
\text { - } \quad \text { Increased fecal Oscillibacter genus. } \\
\text { Lactobacillus and Oscillibacter levels correlated } \\
\text { with transepithelial resistance of the proximal } \\
\text { colon. }\end{array}$ \\
\hline [102] & $\begin{array}{l}\text { Hildebrandt } \\
\text { et al. }\end{array}$ & 2009 & $\begin{array}{l}\text { Control mice (13-week } \\
\text { chow diet) or Restin-like } \\
\text { molecule (RELM)- } \beta \\
\text { knockout mice switched to } \\
\text { HFD for } 21 \text { weeks }\end{array}$ & $\begin{array}{l}\text { - Reduced Bacteroidetes and increased Firmi- } \\
\text { cutes and Proteobacteria phyla associated with } \\
\text { switch to HFD. } \\
\text { HFD (independent of obesity) was mainly re- } \\
\text { sponsible for the observed changes in micro- } \\
\text { biota. }\end{array}$ \\
\hline [107] & Turnbaugh et al. & 2006 & $\begin{array}{l}\text { Genetically obese mice } \\
\text { (ob/ob) vs. control }\end{array}$ & $\begin{array}{l}\text { - Germ-free mice colonized with obese micro- } \\
\text { biota led to increased total body fat }\end{array}$ \\
\hline Reference & Authors & $\begin{array}{l}\text { Year of } \\
\text { Study }\end{array}$ & Subjects & Study Findings for Obese vs. Control \\
\hline [108] & Da Selva & 2020 & $\begin{array}{l}21 \text { children with } \\
\text { obesity/overweight vs. } \\
30 \text { healthy (Caribbean } \\
\text { island of Trinidad) }\end{array}$ & $\begin{array}{l}\text { Reduced alpha diversity was shown compared to } \\
\text { lean children. } \\
\text { Firmicutes was associated with overweight/obese } \\
\text { children. } \\
\text { Bifidobacterium was associated with healthy weight } \\
\text { children. }\end{array}$ \\
\hline [109] & Gao et al. & 2018 & $\begin{array}{c}71 \text { obese and } 22 \\
\text { overweight vs. } 25 \\
\text { healthy }\end{array}$ & $\begin{array}{l}\text { Reduced gut microbial diversity and reduced } \\
\text { beneficial bacteria, e.g., Faecalibacterium, Bifidobac- } \\
\text { terium, and Ruminococcaceae. } \\
\text { Increased levels of Proteobacteria (Pseudomonas, } \\
\text { Fusobacterium, Escherichia, and Shigella). }\end{array}$ \\
\hline
\end{tabular}


Table 6. Cont.

\begin{tabular}{|c|c|c|c|c|}
\hline Reference & Authors & $\begin{array}{l}\text { Year of } \\
\text { Study }\end{array}$ & Subjects & Study Findings for Obese vs. Control \\
\hline [110] & Kalliomäki et al. & 2008 & $\begin{array}{l}25 \text { obese vs. } 24 \text { normal } \\
\text { children (prospective } \\
\text { follow-up study from } \\
\text { children } 3 \text { months to } 7 \text { years) }\end{array}$ & $\begin{array}{l}\text { - Children who had higher levels of Bifidobac- } \\
\text { teria maintained a normal weight over time, } \\
\text { whereas children who had greater levels of } \\
\text { Staphylococcus aureus became overweight. }\end{array}$ \\
\hline [111] & Collado et al. & 2008 & $\begin{array}{l}18 \text { overweight pregnant } \\
\text { women vs. } 36 \text { normal-weight } \\
\text { pregnant women } \\
\text { (prospective follow-up study } \\
\text { during pregnancy) }\end{array}$ & $\begin{array}{l}\text { - High Bacteroidetes concentrations before } \\
\text { pregnancy were associated with excessive } \\
\text { weight gain during pregnancy. } \\
\text { BMI and mother's weight correlated with } \\
\text { concentrations of Clostridium, Bacteroidetes, } \\
\text { and Staphylococcus. } \\
\text { Microbial counts were increased in the third } \\
\text { trimester of pregnancy compared to the first } \\
\text { trimester. }\end{array}$ \\
\hline
\end{tabular}

Briefly, microbial diversity was reduced in obese individuals compared to the healthy controls [108,109]. Significant increases in the levels of Proteobacteria phylum [102,109], Staphylococcus aureus species [110,111], and Bacteroides genus [111] were demonstrated with obesity. Bacteroidetes phylum [102] and the levels of beneficial microbiota such as Bifidobacterium genus [109-111], anti-inflammatory Faecalibacterium, and butyrate-producing Ruminococcaceae were reduced due to obesity [109]. Contrary to T1D and T2D, Firmicutes levels were mostly increased in human and mice models of obesity-induced by HFD [102-104,108]. However, animal data related to the changes in gut microbiota profiles due to obesity are not consistent and seem to depend on the diet type, and genetic background of the animal used [105].

Interestingly, when isolated microbiota from obese animals was transplanted (by oral gavage) into the colon of a germ-free animal, obesity developed after 14 days. In contrast, germ-free animals remained lean after fecal transplantation from a lean animal; although, transplantation of the gut microbiota from a chow-fed germ-exposed mouse to a germ-free mouse led to a $60 \%$ body weight gain after two weeks [112]. Similarly, Turnbaugh et al. demonstrated that colonization of germ-free mice with obese microbiota increased total body fat [107], supporting the role of microbiota in the development of obesity. Stool transplantation from telmisartan-treated mice to obese mice attenuated body weight due to HFD [104]. Interestingly, Collado et al. demonstrated an increase in microbial counts during pregnancy. High Bacteroidetes concentrations before pregnancy were associated with excessive weight gain during pregnancy, and the mother's weight and body mass index correlated with the concentrations of Clostridium, Bacteroidetes, and Staphylococcus [111]. This suggests that the microbiota composition before the onset of pregnancy and during pregnancy may have an important role in the development of metabolic disease in the mothers and adverse fetal outcomes or obesity in the offspring. Furthermore, a prospective follow-up study of children between the age of 3 months and 7 years demonstrated that children who had higher levels of Bifidobacteria maintained a normal weight over time, whereas children who had greater numbers of Staphylococcus aureus became overweight [110]. These data suggest that gut microbiota composition can be used to identify individuals at risk of obesity and that modulating the microbiota can provide a novel preventative measure or therapeutic option for weight management.

The mechanisms by which the gut microbiota interacts with obesity are not fully elucidated. The inflammatory responses observed in response to gut bacteria are likely to play a key role. Bacteria produce lipopolysaccharide (LPS), which induces inflammation and oxidative stress by being absorbed by the intestines, so-called metabolic endotoxemia. Lipid A is a structural ingredient of LPS that induces the activation of different pro- 
inflammatory pathways, leading to increased oxidative stress by binding to its receptor, TLR4 $[113,114]$. The low-grade inflammation induced by the pro-inflammatory cytokines such as IL- 6 and TNF- $\alpha$ leads to metabolic dysfunction detected in obesity [115].

Another obesogenic mechanism is the inhibition of the fasting-induced adipose factor (FIAF) expressed in adipose tissue, liver, and intestines. FIAF suppresses the circulating lipoprotein lipase (LPL) enzyme and regulates the metabolism of triglycerides [116]. As the active LPL enzyme stimulates lipoprotein formation, such as chylomicrons and very lowdensity lipoprotein from triglycerides, FIAF stimulates the segregation of this active LPL enzyme (dimers) into inactive LPL enzyme (monomers) in mice [117]. Bäckhed et al., in an animal study on obese germ-free FIAF ${ }^{-/-}$mice, suggested that gut microbiota regulates the storage of energy by FIAF modulation in the mice, and it is a key factor that regulates the energy harvest from food [112]. The administration of Bacteroides thetaiotaomicron and Methanobrevibacter smithii diminished FIAF production, which leads to increased activity of lipoprotein lipase enzyme and hence increased triglyceride-derived fatty acids storage in adipose tissue and liver $[9,118]$.

The metabolites derived from the gut microbiota, namely LPS and SCFAs, contribute to host obesity and fat storage [119-121]. SCFAs are known to increase leptin release from mouse adipose tissue, resulting in appetite inhibition, metabolic rate enhancement, and reduced obesity in mice and humans [30,122]. GPR-43 deficient mice on a normal diet are obese; however, mice overexpressing GPR-43 in adipose tissue stay lean, even if on a high-fat diet [123]. Thus, demonstrating that GPR-43 is involved in regulating energy utilization. Other animal studies which explored the relationship between gut microbiota and obesity through tryptophan-derived metabolites showed that the dysregulation of tryptophan-derived metabolites results in the development of white adipose tissue and insulin sensitivity, ultimately resulting in obesity $[107,124]$.

\section{The Role of the Gut Microbiota in Chronic Kidney Disease}

There is growing evidence to support the role of gut microbiota in the development and progression of CKD, which may at least partly explain why some people develop progressive disease whilst others are seemingly unaffected. Decreased levels of the beneficial gut microbes, their associated SCFAs, and increased levels of harmful microbes were associated with CKD development [125]. In the context of any form of CKD, there is increased permeability of the intestinal barrier leading to transfer of toxins into the blood circulation; the effect is self-perpetuating in CKD, given the context of impaired renal function, endotoxins accumulate in the blood contributing to persistent systemic inflammation, pro-inflammatory cytokine release, and oxidative stress [125-130]. Collectively, these data provide proof of concept for the potential role of microbiota in limiting renal fibrosis.

Recent animal and clinical studies have linked gut dysbiosis with diabetes-related complications, including retinopathy, neuropathic foot ulcer, atherosclerosis, hypertension [100], and CKD (summarised in Tables 7 and 8). 
Table 7. Animal studies of the gut microbiota in CKD.

\begin{tabular}{|c|c|c|c|c|}
\hline Reference & Authors & $\begin{array}{l}\text { Year of } \\
\text { Study }\end{array}$ & Animal Species & Study Findings in Diseased Group vs. Control \\
\hline [131] & Nishiyama et al. & 2019 & $\begin{array}{l}\text { CKD mice (5/6 } \\
\text { nephrectomy) vs. } \\
\text { controls }\end{array}$ & $\begin{array}{l}\text { - Reduced Lactobacillus, Oscillospira, and unclassi- } \\
\text { fied Ruminococcaceae genera in mice with CKD } \\
\text { while Bifidobacterium, Turicibacter, and Allobaculum } \\
\text { genera were increased. }\end{array}$ \\
\hline [132] & Yang et al. & 2018 & $\begin{array}{l}\text { Adenine-induce CKD } \\
\text { mice vs. control group } \\
\text { (with and without } \\
\text { prebiotic fiber) }\end{array}$ & $\begin{array}{l}\text { - Prebiotic supplementation reduced Clostridium, } \\
\text { Erysipelotrichaceae, unclassified Lactobacillus, Al- } \\
\text { lobaculum, Staphylococcus, and Dorea levels but } \\
\text { had no effect on Ruminococcus, Blautia, and Co- } \\
\text { probacillus. }\end{array}$ \\
\hline [133] & Yang et al. & 2015 & $\begin{array}{l}\text { Spontaneous } \\
\text { hypertensive rats and } \\
\text { angiotensin II-infused } \\
\text { chronic hypertensive } \\
\text { rats compared to } \\
\text { controls }\end{array}$ & $\begin{array}{l}\text { - Decreased microbial diversity in hypertensive rats } \\
\text { vs. controls. } \\
\text { Firmicutes: Bacteroidetes ratio was increased, } \\
\text { associated with reduced acetate and butyrate- } \\
\text { producing bacteria. }\end{array}$ \\
\hline [134] & Vaziri et al. & 2013 & $\begin{array}{l}\text { CKD (5/6 nephrectomy } \\
\text { rats) vs. control }\end{array}$ & $\begin{array}{l}\text { - Rats with chronic renal failure showed increased } \\
\text { Betaproteobacteria class but decreased Actinobac- } \\
\text { teria, Proteobacteria phyla, Lactobacillaceae, Pre- } \\
\text { votellaceae families, Clostridia, Mollicutes, Bacilli, } \\
\text { and Bacteroidiaclass. }\end{array}$ \\
\hline [135] & Tanida et al. & 2005 & $\begin{array}{l}\text { Hypertensive Wistar } \\
\text { rats vs. healthy rats } \\
\text { (administered with } \\
\text { Lactobacillus johnsonii } \\
\text { probiotic) }\end{array}$ & $\begin{array}{l}\text { - Administration of Lactobacillus johnsonii reduced } \\
\text { blood pressure and might be due to altering renal } \\
\text { sympathetic nerve activity. }\end{array}$ \\
\hline [136] & Kawase et al. & 2000 & $\begin{array}{l}\text { Rats fed fermented } \\
\text { milk with Streptococcus } \\
\text { thermophilus, } \\
\text { Lactobacillus casei, or } \\
\text { both vs. control }\end{array}$ & $\begin{array}{l}\text { Atherogenic index, systolic blood pressure, and } \\
\text { total serum cholesterol level were reduced. }\end{array}$ \\
\hline
\end{tabular}

As in T1D and T2D, a decrease in microbial diversity was also shown in hypertensive rats vs. controls. However, the Firmicutes: Bacteroidetes ratio was increased in hypertensive rats, and this was associated with reduced acetate and butyrate-producing bacteria [133]. Mice with CKD also had reduced levels of Lactobacillus, Oscillospira, and unclassified Ruminococcaceae genera and increased levels of Bifidobacterium, Turicibacter, and Allobaculum genera, leading to inflammation and renal failure [131]. Using an adenineinduced CKD mice model, Yang et al. demonstrated that nine bacterial genera were enriched in CKD, six of which were reduced with fiber supplements [132]. In addition, Tanida et al. showed a decrease in blood pressure following administration of hypertensive rats with Lactobacillus johnsonii species [135]. Furthermore, Kawase et al. showed decreased systolic blood pressure and total cholesterol level and increased HDL after feeding humans and rats with fermented milk containing Streptococcus thermophilus and Lactobacillus casei compared to the healthy groups which were not administered with fermented milk [136]. Collectively, these studies support the role of gut microbiota in CKD and suggest that modulation of the microbiota can impact CKD development or progression.

There is also mounting evidence in humans demonstrating a link between gut dysbiosis and CKD (Table 8). Vallianou et al. reviewed several human studies of gut microbiota in hypertensive patients, finding a high correlation between high blood pressure, and 
decreased gut microbial diversity, and serum markers of inflammation. They postulated that gut dysbiosis and inflammation impact the kidney by sympathomimetic changes through changes in plasma metabolite secretion, plasma metabolite retention, and body fluid homeostasis [137]. The specific changes, unique or otherwise, in the context of diabetic kidney disease, have been poorly described within human studies. The imbalance of gut microbiota in CKD occurred both quantitatively and qualitatively and is often accompanied by increased levels of Lachnospiraceae, Enterobacteriaceae, and certain Ruminococcaceae, and a reduction in some species of Bacteroidaceae, Lactobacillus, Prevotellaceae, and Bifidobacterium [138].

Reduced bacterial diversity was shown in hypertensive patients and in patients with CKD compared to healthy controls $[19,133]$. As shown in hypertensive rats, Yang et al. demonstrated that the Firmicutes: Bacteroidetes ratio was also increased in hypertensive patients, and this was associated with reduced acetate and butyrate producing bacteria [133]. The levels of opportunistic pathogens from gamma-proteobacteria were also increased in patients with CKD. However, beneficial microbes like Roseburia, Coprococcus, and Ruminococcaceae were decreased [19]. It is not clear whether renal function affects dysbiosis or vice versa, but $\mathrm{Xu}$ et al. have demonstrated that impaired renal function and dysbiosis in the gut microbiota increased the plasma concentration of trimethylamine-N-oxide [19] involved in cardiovascular disease and atherosclerosis [139] and hence increased disease comorbidities/complications.

Table 8. Studies of the gut microbiota in chronic kidney disease (CKD) in humans.

\begin{tabular}{|c|c|c|c|c|}
\hline Reference & Authors & Year & Patient Group & Study Findings in Diseased Group vs. Control \\
\hline [144] & Jiang et al. & 2017 & $\begin{array}{l}52 \text { with ESKD vs. } 60 \\
\text { healthy }\end{array}$ & $\begin{array}{l}\text { - Switch from Prevotella (enterotype 2) to Bacteroides } \\
\text { (enterotype 1) was associated with a reduction of } \\
\text { butyrate-producing bacteria. }\end{array}$ \\
\hline [19] & Xu et al. & 2017 & 32 CKD vs.32 healthy & $\begin{array}{l}\text { - Reduced bacterial diversity. } \\
\text { The levels of opportunistic pathogens from } \\
\text { gamma-proteobacteria were increased. However, } \\
\text { beneficial microbes like Coprococcus, Roseburia, and } \\
\text { Ruminococcaceae were decreased. } \\
\text { Impaired renal function and gut microbiota } \\
\text { dysbiosis increased plasma concentrations of } \\
\text { trimethylamine-N-oxide involved in cardiovascu- } \\
\text { lar disease. }\end{array}$ \\
\hline [145] & Salgado et al. & 2016 & $\begin{array}{l}\text { Pediatric patients; } 8 \text { on } \\
\text { peritoneal dialysis, } 8 \\
\text { hemodialysis } 10 \text { post } \\
\text { kidney transplants } \\
\text { vs. } 13 \text { healthy }\end{array}$ & $\begin{array}{l}\text { Lower bacterial species richness was demon- } \\
\text { strated in peritoneal dialysis and post-transplant } \\
\text { patients compared with healthy individuals and } \\
\text { patients on hemodialysis. }\end{array}$ \\
\hline [140] & Jiang et al. & 2016 & $\begin{array}{l}65 \text { CKD } \\
\text { (Stage } 1-5) \text { vs. } 20 \\
\text { healthy }\end{array}$ & $\begin{array}{l}\text { - Reduced butyrate-producing bacteria Faecalibac- } \\
\text { terium prausnitzii and Roseburia spp. with a mild } \\
\text { reduction in kidney function in comparison with } \\
\text { healthy individuals. }\end{array}$ \\
\hline [133] & Yang et al. & 2015 & $\begin{array}{l}7 \text { Hypertensive patients } \\
\text { vs. } 10 \text { healthy }\end{array}$ & $\begin{array}{l}\text { - } \quad \text { Reduced bacterial diversity. } \\
\text { - Increased Firmicutes: Bacteroidetes ratio. }\end{array}$ \\
\hline
\end{tabular}


Table 8. Cont.

\begin{tabular}{|c|c|c|c|c|}
\hline Reference & Authors & Year & Patient Group & Study Findings in Diseased Group vs. Control \\
\hline [146] & Wong et al. & 2014 & $\begin{array}{l}24 \text { patients with ESKD } \\
\text { undergoing } \\
\text { hemodialysis vs. } 12 \\
\text { healthy }\end{array}$ & $\begin{array}{l}\text { - Expansion in the bacterial families that possess } \\
\text { uricase, urease, indole, and p-cresol-forming } \\
\text { enzymes and a reduction in bacterial families } \\
\text { with butyrate-forming capability compared with } \\
\text { healthy individuals. }\end{array}$ \\
\hline [134] & Vaziri et al. & 2013 & $\begin{array}{l}24 \text { patients with ESKD } \\
\text { undergoing } \\
\text { hemodialysis vs. } 12 \\
\text { healthy }\end{array}$ & $\begin{array}{l}\text { Difference in the abundance of ca. } 190 \text { microbial } \\
\text { operational taxonomic units (OTU) when the gut } \\
\text { microbiota was compared to healthy controls. }\end{array}$ \\
\hline [147] & I. Wang et al. & 2012 & $\begin{array}{l}29 \text { patients with ESKD } \\
\text { undergoing PD vs. } 41 \\
\text { healthy }\end{array}$ & $\begin{array}{l}\text { - Abundances of Bifidobacterium and Lactobacillus } \\
\text { spp. (B. Catenulatum, B. longum, B. bifidum, L. } \\
\text { plantarum, and L. paracasei) were reduced com- } \\
\text { pared with healthy individuals. }\end{array}$ \\
\hline [148] & Wang et al. & 2012 & $\begin{array}{l}30 \text { patients with ESKD } \\
\text { not on dialysis vs. } 10 \\
\text { healthy }\end{array}$ & $\begin{array}{l}\text { - Bacterial DNA detected in the blood of } 20 \% \text { of } \\
\text { patients. } \\
\text { Bacterial genera identified in the patient's blood } \\
\text { were overgrown in the guts of the same patients. }\end{array}$ \\
\hline [141] & $\begin{array}{l}\text { Ranganathan } \\
\text { et al. }\end{array}$ & 2009 & $\begin{array}{l}13 \text { patients with CKD } \\
(\text { Stage } 3 \text { and } 4)\end{array}$ & $\begin{array}{l}\text { - Decreased levels of culturable anaerobic bacteria } \\
\text { were shown in the feces of patients with CKD } \\
\text { compared to healthy controls. }\end{array}$ \\
\hline [142] & Fukuuchi et al. & 2002 & $\begin{array}{l}27 \text { patients with } \\
\text { chronic kidney failure } \\
\text { and } 20 \text { patients with } \\
\text { hemodialysis } \\
\text { vs. } 12 \text { healthy controls }\end{array}$ & $\begin{array}{l}\text { Culturable aerobic bacteria levels were increased } \\
\text { in the feces of patients with CKD, not yet on dialy- } \\
\text { sis, when compared with healthy adults. }\end{array}$ \\
\hline [143] & Hida et al. & 1996 & $\begin{array}{l}\text { ESKD patients } 20 \text { with } \\
\text { hemodialysis vs. } 12 \\
\text { healthy controls }\end{array}$ & $\begin{array}{l}\text { - Aerobic bacteria, including the Enterococci and En- } \\
\text { terobacteria species, were increased in quantity in } \\
\text { patients with ESKD compared with healthy con- } \\
\text { trols. }\end{array}$ \\
\hline
\end{tabular}

Patients with mild kidney function have reduced butyrate-producing bacteria Roseburia spp. and Faecalibacterium prausnitzii compared with healthy individuals [140]. A reduced level of culturable anaerobic bacteria was also seen in the feces of these patients compared to healthy controls [141]. However, an increase in culturable aerobic bacteria (such as Enterococci and Enterobacteria species) was detected in the feces of patients with CKD who had not started dialysis [142] and in patients with ESKD compared with healthy adults [143].

Peritoneal dialysis and post-transplant patients also had lower bacterial species richness compared with healthy individuals and patients on hemodialysis; interestingly, this was associated with reduced levels of Firmicutes and Bifidobacteria and increased levels of Bacteroidetes [145]. Patients with ESKD have abundant levels of bacterial families that possess uricase, urease, indole, and p-cresol-forming enzymes and a lower level of bacterial families with butyrate-forming capacity compared with healthy individuals [144,146]. In addition, they have reduced levels of Bifidobacterium and Lactobacillus spp. compared with healthy individuals [147]. Overall, the abundance of approximately 190 microbial operational taxonomic units were significantly different when comparing patients with ESKD undergoing hemodialysis and healthy controls [134]. Interestingly, bacterial genera grown in the guts of patients with ESKD (such as Klebsiella, Escherichia, Proteus, Enterobacter, 
and Pseudomonas spp.) were also detected in the blood of $20 \%$ of the patients. This was associated with increased levels of IL-6, C-reactive protein, and plasma D-lactate [148], which demonstrate that bacterial translocation can occur in patients with ESKD and contribute to microinflammation in this population.

Although the above strongly supports the role of the microbiota in CKD, it is still unclear whether changes in the microbiota are causative of the disease or occur as a consequence of CKD. It is yet to be established whether the microbiota can be used as predictive markers for CKD progression. The mechanism/s whereby the microbiota can influence the rate of progression of CKD is, to date, not well described. It is known that SCFAs have an important role in autophagy, mitophagy, and oxidative stress [149,150], which we and others have previously demonstrated to be dysregulated in animals with DKD [151-153]; SCFAs have been shown to normalize autophagy and improve renal dysfunction in a mice model of acute kidney injury [150]. Furthermore, SCFAs have also been shown to have renoprotective effects in experimentally induced diabetic rats [154]. Infusion of the SCFA butyrate decreases extracellular matrix accumulation associated with podocyte injury in the glomerular basement membrane of the kidney in Gpr109a ${ }^{-/-}$male mice [52]. Furthermore, butyrate lowers renal inflammation, as indicated by the reduction in pro-inflammation cytokine levels of IL1 $\beta$ and tumor necrosis factor (TNF) $\alpha$ [52]. Recent studies have demonstrated that SCFAs improve blood pressure regulation by activating the two receptors, Olfr-78 and GPR-41 [55,155], which in turn modulate renin secretion and vascular tone [156]. The decrease in systolic blood pressure and total cholesterol levels reduce the risk of ischemic heart and cerebral disease often seen in patients with CKD and potentially reduce $\mathrm{CKD}$ progression.

\section{Regulation of the Gut Microbiota as a Potential Treatment for Diabetic Kidney Disease}

Glucose-lowering agents are used to treat diabetes and restore glucose homeostasis. Despite the large number of glucose-lowering agents available for the treatment of T2D, only $40 \%$ of people with diabetes achieve optimal glycemic control $[157,158]$. Increasingly, glucose-lowering agents, such as the sodium glucose-like transporter-2 inhibitors (SGLT2i) and glucose-like peptide-1 receptor agonists (GLP-1Ra), are recognized to have pleiotropic effects beyond glucose-lowering, including bodyweight reduction, blood pressure reduction, and cardiovascular protection $[159,160]$. SGLT-2 inhibitors have been shown to have renoprotective qualities, with the largest clinical trial CREDENCE demonstrating the reduced progression of renal impairment in people with established DKD [161]. The dapagliflozin CKD study also demonstrated renoprotection in patients with DKD and non-diabetic kidney disease [162]. Treatments that wholistically improve glycemia, reduce body weight and blood pressure, and offer cardiorenal protection to patients with T2D are clearly the most desirable for the patient, clinician, and health system.

Manipulating the gut microbiota may provide an additional treatment to prevent or treat T2D and DKD $[163,164]$. Diet is the most influential short- and long-term modulator affecting the gut microbiota. Dietary fibers are widely recognized as an important part of a healthy diet. However, all fibers have not proven to be equal [165]. Recent research has indicated that whole-plant fibers from growing vegetable matter contain a number of important micronutrients, whereas highly processed fibers or fibers from seed coats have reduced nutritional value [166]. Sugarcane bioflavonoids, for example, have been shown to reduce the postprandial glycemic response to high glycemic index starchy foods [167]. Interestingly, recent reports have demonstrated superior benefits from antioxidants found in natural fiber sources compared to purified supplemental antioxidants $[168,169]$.

Prebiotics are dietary supplements that contain fermentable fibers resulting in a health benefit to their host. The most common form of these is non-absorbable dietary fiber. They cannot be hydrolyzed or absorbed by the gastrointestinal tract, but rather they are selectively fermented by intestinal and colonic bacteria. It is reported that dietary supplementation of prebiotics positively modulates and normalizes the microbiota by eliminating pathogens and promoting the growth of beneficial microorganisms [170,171]. Prebiotics 
can also improve the function of the mucosal barrier and mitigate immune reactions in patients with irritable bowel syndrome [170,172-175]. Modulating the microbiota has shown beneficial effects in patients with obesity and T2D [9]. Prebiotics can also significantly lower fasting blood sugar in patients with T2D [176]. The prebiotic inulin has been shown to reduce adiposity, cholesterol and enhance glucose metabolism in wild-type mice with diet-induced obesity [177]. Diabetic rats receiving inulin had decreased insulin resistance, fasting blood glucose and serum insulin levels, and increased fasting serum GLP-1 levels [178]. In human studies, inulin intake can increase rates of SCFAs in overweight-obese men as it improves fat oxidation and metabolism [179].

Probiotics are live microorganisms introduced into the gut for potential beneficial effects by promoting the growth of healthy bacteria. Dietary supplementation with the probiotics Lactobacillus rhamnosus, Lactobacillus paracasei, or Bifidobacterium animalis diminished the obesogenic effects of a high-fat diet in mice and reduced weight gain. Furthermore, probiotics may assist with glucose-insulin equilibrium as glucose levels were quicker to normalize in mice who received probiotics following an oral glucose bolus [180]. However, Lactobacillus fermentum, Lactobacillus acidophilus, and Lactobacillus ingluviei were associated with weight gain [181]. The outcomes of human studies are mixed. A meta-analysis study showed that the effect of Lactobacillus-containing probiotics also varies based on the species used. A significant weight gain was demonstrated in humans administered with Lactobacillus acidophilus, as an example, while Lactobacillus gasseri was associated with weight loss in obese humans [181]. In addition, when human fecal samples were studied, obesity was associated with higher levels of Lactobacillus reuteri regardless of the probiotic use [182].

Complementary medicines and natural healthcare supplements are widely embraced by the global community. Almost four out of ten American adults indicated that they used complementary medicines $[183,184]$. More studies are needed to explore the beneficial effects of prebiotic and probiotic use in the prevention and complementary treatment of DKD.

\section{Fecal Microbiota Transplantation}

There is increasing interest in fecal microbiota transplantation (FMT) as a treatment for various disease states, with the strongest evidence occurring for people with Clostridium difficile-induced colitis $[185,186]$. Conceptually, FMT involves infusion of the gut microbiota from a healthy subject to an unhealthy subject, altering their gut microbiota and influencing the disease state. Transfer of intestinal microbiota from a lean individual to a person with a metabolic syndrome was shown to significantly alter the intestinal microbiota in favor of the increased presence of butyrate-producer Eubacterium hallii, conferring a significant improvement in peripheral insulin sensitivity 6 weeks after the gut microbiota transplant [187]. Improved hepatic insulin sensitivity was also observed despite no change in dietary composition, resting energy expenditure, or hormonal changes. Using an obstructive sleep apnea-induced hypertensive model, which is known to decrease kidney function, Durgan et al. demonstrated that transplant of dysbiotic caecal contents from hypertensive to normotensive rats caused hypertension in the recipient [158], supporting the role of dysregulated gut microbiota in CKD. To our knowledge, FMT has not been undertaken in patients with DKD.

\section{Conclusions}

The association between gut microbiota and diabetes, obesity, and kidney disease have been well established. The increasing evidence for the association between gut dysbiosis and DKD confirms the gut-kidney interrelationship, yet the causal role of gut dysbiosis and DKD development and progression remains less clear. Nonetheless, effective natural-based therapies that can improve glycemic control, provide favorable metabolic benefits, and prevent diabetes-related complications are increasingly sought. Dietary manipulation, prebiotics, and probiotics are widely acceptable to patients in light of their general safety, low regulatory constraints, and quick route to market. Hence, manipulation 
of the microbiota, whether by fibers, prebiotics, probiotics, complementary medicines, or fecal microbiota transplant may offer a natural and safe addition to the treatment armamentarium for patients with diabetes and kidney-related disease.

Author Contributions: A.Z., S.J.G., M.Y.W.W., C.A.P. and S.S. contributed to the review writing. C.A.P. and S.S. critically edited the review. All authors have read and agreed to the published version of the manuscript.

Funding: This research received no external funding.

Institutional Review Board Statement: Not applicable.

Informed Consent Statement: Not applicable.

Data Availability Statement: Not applicable.

Conflicts of Interest: The authors declare no conflict of interest.

\section{References}

1. Atkins, R.C.; Zimmet, P. Diabetic kidney disease: Act now or pay later. Med. J. Aust. 2010, 192, 272-274. [CrossRef]

2. IDF. Q\&A: Key points for IDF Diabetes Atlas 2017. Diabetes Res. Clin. Pract. 2018, 135, 235-236.

3. Phillips, A.O. Diabetic nephropathy. Medicine 2011, 39, 470-474. [CrossRef]

4. Vinod, P. Pathophysiology of diabetic nephropathy. Clin. Queries: Nephrol. 2012, 1, 121-126. [CrossRef]

5. Couser, W.G.; Remuzzi, G.; Mendis, S.; Tonelli, M. The contribution of chronic kidney disease to the global burden of major noncommunicable diseases. Kidney Int. 2011, 80, 1258-1270. [CrossRef] [PubMed]

6. Qin, J.; MetaHIT Consortium; Li, R.; Raes, J.; Arumugam, M.; Burgdorf, K.; Manichanh, C.; Nielsen, T.; Pons, N.; Levenez, F.; et al. A human gut microbial gene catalogue established by metagenomic sequencing. Nature 2010, 464, 59-65. [CrossRef]

7. Niu, J.; Xu, L.; Qian, Y.; Sun, Z.; Yu, D.; Huang, J.; Zhou, X.; Wang, Y.; Zhang, T.; Ren, R.; et al. Evolution of the Gut Microbiome in Early Childhood: A Cross-Sectional Study of Chinese Children. Front. Microbiol. 2020, 11, 439. [CrossRef]

8. Wopereis, H.; Oozeer, R.; Knipping, K.; Belzer, C.; Knol, J. The first thousand days-Intestinal microbiology of early life: Establishing a symbiosis. Pediatr. Allergy Immunol. 2014, 25, 428-438. [CrossRef]

9. Muñoz-Garach, A.; Diaz-Perdigones, C.; Tinahones, F.J. Gut microbiota and type 2 diabetes mellitus. Endocrinología Nutrición (Engl. Ed.) 2016, 63, 560-568. [CrossRef]

10. Zhernakova, A.; Kurilshikov, A.; Bonder, M.J.; Tigchelaar, E.F.; Schirmer, M.; Vatanen, T.; Mujagic, Z.; Vila, A.V.; Falony, G.; Vieira-Silva, S.; et al. Population-based metagenomics analysis reveals markers for gut microbiome composition and diversity. Science 2016, 352, 565-569. [CrossRef] [PubMed]

11. Lazar, V.; Ditu, L.-M.; Pircalabioru, G.G.; Picu, A.; Petcu, L.; Cucu, N.; Chifiriuc, M.C. Gut Microbiota, Host Organism, and Diet Trialogue in Diabetes and Obesity. Front. Nutr. 2019, 6, 21. [CrossRef] [PubMed]

12. Maslowski, K.; Vieira, A.; Ng, A.; Kranich, J.; Sierro, F.; Yu, D.; Schilter, H.; Rolph, M.S.; Mackay, F.; Artis, D.; et al. Regulation of inflammatory responses by gut microbiota and chemoattractant receptor GPR43. Nature 2009, 461, 1282-1286. [CrossRef] [PubMed]

13. Belkaid, Y.; Harrison, O. Homeostatic Immunity and the Microbiota. Immunity 2017, 46, 562-576. [CrossRef] [PubMed]

14. Spasova, D.S.; Surh, C.D. Blowing on Embers: Commensal Microbiota and Our Immune System. Front. Immunol. 2014, 5, 318. [CrossRef]

15. Nallu, A.; Sharma, S.; Ramezani, A.; Muralidharan, J.; Raj, D. Gut microbiome in chronic kidney disease: Challenges and opportunities. Transl. Res. 2016, 179, 24-37. [CrossRef] [PubMed]

16. Meijers, B.; Evenepoel, P.; Anders, H.-J. Intestinal microbiome and fitness in kidney disease. Nat. Rev. Nephrol. 2019, 15, 531-545. [CrossRef]

17. Lovre, D.; Shah, S.; Sihota, A.; Fonseca, V.A. Managing Diabetes and Cardiovascular Risk in Chronic Kidney Disease Patients. Endocrinol. Metab. Clin. N. Am. 2017, 47, 237-257. [CrossRef]

18. Alwardat, N.; Di Renzo, L.; De Lorenzo, A. Comment on "The Gut Microbiome Profile in Obesity: A Systematic Review". Int. J. Endocrinol. 2018, 2018, 6015278. [CrossRef] [PubMed]

19. Xu, K.Y.; Xia, G.H.; Lu, J.Q.; Chen, M.X.; Zhen, X.; Wang, S.; You, C.; Nie, J.; Zhou, H.W.; Yin, J. Impaired renal function and dysbiosis of gut microbiota contribute to increased trimethylamine-N-oxide in chronic kidney disease patients. Sci. Rep. 2017, 7, 1445. [CrossRef] [PubMed]

20. Fernandes, R.; Viana, S.; Nunes, S.R.R.P.; Reis, F. Diabetic gut microbiota dysbiosis as an inflammaging and immunosenescence condition that fosters progression of retinopathy and nephropathy. Biochim. Biophys. Acta (BBA) Mol. Basis Dis. 2018, 1865, 1876-1897. [CrossRef]

21. Vaziri, N.D.; Zhao, Y.-Y.; Pahl, M.V. Altered intestinal microbial flora and impaired epithelial barrier structure and function in CKD: The nature, mechanisms, consequences and potential treatment. Nephrol. Dial. Transplant. 2015, 31, 737-746. [CrossRef]

22. Luckey, T.D. Introduction to intestinal microecology. Am. J. Clin. Nutr. 1972, 25, 1292-1294. [CrossRef] 
23. Tojo, R.; Suárez, A.; Clemente, M.G.; Reyes-Gavilan, C.D.L.; Margolles, A.; Gueimonde, M.; Ruas-Madiedo, P. Intestinal microbiota in health and disease: Role of bifidobacteria in gut homeostasis. World J. Gastroenterol. 2014, 20, 15163-15176. [CrossRef]

24. Arumugam, M.; MetaHIT Consortium (Additional Members); Raes, J.; Pelletier, E.; Le Paslier, D.; Yamada, T.; Mende, D.R.; Fernandes, G.D.R.; Tap, J.; Bruls, T.; et al. Enterotypes of the human gut microbiome. Nature 2011, 473, 174-180. [CrossRef] [PubMed]

25. Rinninella, E.; Raoul, P.; Cintoni, M.; Franceschi, F.; Miggiano, G.A.; Gasbarrini, A.; Mele, M.C. What is the Healthy Gut Microbiota Composition? A Changing Ecosystem across Age, Environment, Diet, and Diseases. Microorganisms 2019, 7, 14. [CrossRef] [PubMed]

26. Anderson, J.R.; Carroll, I.; Azcarate-Peril, M.A.; Rochette, A.D.; Heinberg, L.J.; Peat, C.; Steffen, K.; Manderino, L.M.; Mitchell, J.; Gunstad, J. A preliminary examination of gut microbiota, sleep, and cognitive flexibility in healthy older adults. Sleep Med. 2017, 38, 104-107. [CrossRef]

27. Raja, A.; Prabakarana, P. Actinomycetes and Drug-An Overview. Am. J. Drug Discov. Dev. 2011, 1, 75-84. [CrossRef]

28. Maslowski, K.; Mackay, C. Diet, gut microbiota and immune responses. Nat. Immunol. 2010, 12, 5-9. [CrossRef] [PubMed]

29. Eckburg, P.B.; Bik, E.; Bernstein, C.N.; Purdom, E.; Dethlefsen, L.; Sargent, M.; Gill, S.R.; Nelson, K.E.; Relman, D.A. Diversity of the Human Intestinal Microbial Flora. Science 2005, 308, 1635-1638. [CrossRef]

30. Schroeder, B.O.; Bäckhed, F. Biological effects of propionic acid in humans; metabolism, potential applications and underlying mechanisms. Biochim. Biophys. Acta 2010, 1801, 1175-1183.

31. Schroeder, B.O.; Bäckhed, F. Signals from the gut microbiota to distant organs in physiology and disease. Nat. Med. 2016, 22, 1079-1089. [CrossRef]

32. McNeil, N.I. The contribution of the large intestine to energy supplies in man. Am. J. Clin. Nutr. 1984, 39, 338-342. [CrossRef]

33. Wong, J.M.W.; de Souza, R.; Kendall, C.W.C.; Emam, A.; Jenkins, D.J.A. Colonic Health: Fermentation and Short Chain Fatty Acids. J. Clin. Gastroenterol. 2006, 40, 235-243. [CrossRef]

34. McNeil, N.I.; Cummings, J.H.; James, W.P. Short chain fatty acid absorption by the human large intestine. Gut 1978, 19, 819-822. [CrossRef]

35. Cummings, J.H.; Pomare, E.W.; Branch, W.J.; Naylor, C.P.; Macfarlane, G.T. Short chain fatty acids in human large intestine, portal, hepatic and venous blood. Gut 1987, 28, 1221-1227. [CrossRef] [PubMed]

36. Fellows, R.; Denizot, J.; Stellato, C.; Cuomo, A.; Jain, P.; Stoyanova, E.; Balázsi, S.; Hajnády, Z.; Liebert, A.; Kazakevych, J.; et al. Microbiota derived short chain fatty acids promote histone crotonylation in the colon through histone deacetylases. Nat. Commun. 2018, 9, 1-15. [CrossRef]

37. Cummings, J.H.; Hill, M.J.; Bone, E.S.; Branch, W.J.; Jenkins, D.J.A. The effect of meat protein and dietary fiber on colonic function and metabolism II. Bacterial metabolites in feces and urine. Am. J. Clin. Nutr. 1979, 32, 2094-2101. [CrossRef] [PubMed]

38. Huang, W.; Zhou, L.; Guo, H.; Xu, Y.; Xu, Y. The role of short-chain fatty acids in kidney injury induced by gut-derived inflammatory response. Metabolism 2017, 68, 20-30. [CrossRef] [PubMed]

39. Li, L.-Z.; Tao, S.-B.; Ma, L.; Fu, P. Roles of short-chain fatty acids in kidney diseases. Chin. Med. J. 2019, 132, 1228-1232. [CrossRef]

40. Lin, H.; Frassetto, A.; Kowalik, E.J., Jr.; Nawrocki, A.R.; Lu, M.M.; Kosinski, J.R.; Hubert, J.A.; Szeto, D.; Yao, X.; Forrest, G.; et al. Butyrate and Propionate Protect against Diet-Induced Obesity and Regulate Gut Hormones via Free Fatty Acid Receptor 3-Independent Mechanisms. PLoS ONE 2012, 7, e35240. [CrossRef]

41. Ang, Z.; Ding, J.L. GPR41 and GPR43 in Obesity and Inflammation-Protective or Causative? Front. Immunol. 2016, 7, 28. [CrossRef] [PubMed]

42. Singh, N.; Gurav, A.; Sivaprakasam, S.; Brady, E.; Padia, R.; Shi, H.; Thangaraju, M.; Prasad, P.D.; Manicassamy, S.; Munn, D.; et al. Activation of Gpr109a, Receptor for Niacin and the Commensal Metabolite Butyrate, Suppresses Colonic Inflammation and Carcinogenesis. Immunity 2014, 40, 128-139. [CrossRef] [PubMed]

43. Thangaraju, M.; Cresci, G.A.; Liu, K.; Ananth, S.; Gnanaprakasam, J.P.; Browning, D.; Mellinger, J.; Smith, S.B.; Digby, G.J.; Lambert, N.A.; et al. GPR109A Is a G-protein-Coupled Receptor for the Bacterial Fermentation Product Butyrate and Functions as a Tumor Suppressor in Colon. Cancer Res. 2009, 69, 2826-2832. [CrossRef]

44. Yang, S.; Li, X.; Wang, N.; Yin, G.; Ma, S.; Fu, Y.; Wei, C.; Chen, Y.; Xu, W. GPR109A Expression in the Murine Min6 Pancreatic Beta Cell Line, and Its Relation with Glucose Metabolism and Inflammation. Ann. Clin. Lab. Sci. 2015, 45, 315-322. [PubMed]

45. Pluznick, J.L. Renal and cardiovascular sensory receptors and blood pressure regulation. Am. J. Physiol. Physiol. 2013, 305, F439-F444. [CrossRef]

46. Pluznick, J.L.; Protzko, R.J.; Gevorgyan, H.; Peterlin, Z.; Sipos, A.; Han, J.; Brunet, I.; Wan, L.-X.; Rey, F.; Wang, T.; et al. Olfactory receptor responding to gut microbiota-derived signals plays a role in renin secretion and blood pressure regulation. Proc. Natl. Acad. Sci. USA 2013, 110, 4410-4415. [CrossRef]

47. Chang, A.J.; Ortega, F.E.; Riegler, J.; Madison, D.V.; Krasnow, M.A. Oxygen regulation of breathing through an olfactory receptor activated by lactate. Nature 2015, 527, 240-244. [CrossRef] [PubMed]

48. Fleischer, J.; Bumbalo, R.; Bautze, V.; Strotmann, J.; Breer, H. Expression of odorant receptor Olfr78 in enteroendocrine cells of the colon. Cell Tissue Res. 2015, 361, 697-710. [CrossRef]

49. Flegel, C.; Manteniotis, S.; Osthold, S.; Hatt, H.; Gisselmann, G. Expression Profile of Ectopic Olfactory Receptors Determined by Deep Sequencing. PLoS ONE 2013, 8, e55368. [CrossRef] 
50. Zhang, J.; Cheng, S.; Wang, Y.; Yu, X.; Li, J. Identification and characterization of the free fatty acid receptor 2 (FFA2) and a novel functional FFA2-like receptor (FFA2L) for short-chain fatty acids in pigs: Evidence for the existence of a duplicated FFA2 gene (FFA2L) in some mammalian species. Domest. Anim. Endocrinol. 2013, 47, 108-118.e1. [CrossRef] [PubMed]

51. Bolognini, D.; Tobin, A.B.; Milligan, G.; Moss, C.E. The Pharmacology and Function of Short Chain Fatty Acid Receptors. Mol. Pharmacol. 2015, 89, 388-398. [CrossRef]

52. Felizardo, R.J.F.; de Almeida, D.C.; Pereira, R.L.; Watanabe, I.K.M.; Doimo, N.T.S.; Ribeiro, W.R.; Cenedeze, M.A.; Hiyane, M.I.; Amano, M.T.; Braga, T.T.; et al. Gut microbial metabolite butyrate protects against proteinuric kidney disease through epigeneticand GPR109a-mediated mechanisms. FASEB J. 2019, 33, 11894-11908. [CrossRef] [PubMed]

53. Schilderink, R.; Verseijden, C.; De Jonge, W.J. Dietary Inhibitors of Histone Deacetylases in Intestinal Immunity and Homeostasis. Front. Immunol. 2013, 4, 226. [CrossRef] [PubMed]

54. Demigné, C.; Morand, C.; Levrat, M.-A.; Besson, C.; Moundras, C.; Rémésy, C. Effect of propionate on fatty acid and cholesterol synthesis and on acetate metabolism in isolated rat hepatocytes. Br. J. Nutr. 1995, 74, 209-219. [CrossRef] [PubMed]

55. Todesco, T.; Rao, A.V.; Bosello, O.; Jenkins, D.J. Propionate lowers blood glucose and alters lipid metabolism in healthy subjects. Am. J. Clin. Nutr. 1991, 54, 860-865. [CrossRef]

56. Berni Canani, R.; Di Costanzo, M.; Leone, L. The epigenetic effects of butyrate: Potential therapeutic implications for clinical practice. Clin. Epigenetics 2012, 4, 4. [CrossRef] [PubMed]

57. Sun, D.; Chen, Y.; Fang, J.-Y. Influence of the microbiota on epigenetics in colorectal cancer. Natl. Sci. Rev. 2018, 6, 1138-1148. [CrossRef]

58. Lin, M.Y.; De Zoete, M.R.; van Putten, J.; Strijbis, K. Redirection of Epithelial Immune Responses by Short-Chain Fatty Acids through Inhibition of Histone Deacetylases. Front. Immunol. 2015, 6, 554. [CrossRef]

59. Chen, J.S.; Faller, D.V.; Spanjaard, R.A. Short-chain fatty acid inhibitors of histone deacetylases: Promising anticancer therapeutics? Curr. Cancer Drug Targets 2003, 3, 219-236. [CrossRef]

60. Noh, H.; Oh, E.Y.; Seo, J.Y.; Yu, M.R.; Kim, Y.O.; Ha, H.; Lee, H.B. Histone deacetylase-2 is a key regulator of diabetes- and transforming growth factor- $\beta 1$-induced renal injury. Am. J. Physiol. Physiol. 2009, 297, F729-F739. [CrossRef]

61. Yoshikawa, M.; Hishikawa, K.; Marumo, T.; Fujita, T. Inhibition of histone deacetylase activity suppresses epithelial-tomesenchymal transition induced by TGF-beta1 in human renal epithelial cells. J. Am. Soc. Nephrol. JASN 2007, 18, 58-65. [CrossRef]

62. Devaraj, S.; Dasu, M.R.; Rockwood, J.; Winter, W.; Griffen, S.C.; Jialal, I. Increased Toll-Like Receptor (TLR) 2 and TLR4 Expression in Monocytes from Patients with Type 1 Diabetes: Further Evidence of a Proinflammatory State. J. Clin. Endocrinol. Metab. 2008, 93, 578-583. [CrossRef]

63. Mohammad, M.K.; Morran, M.; Slotterbeck, B.; Leaman, D.W.; Sun, Y.; Von Grafenstein, H.; Hong, S.-C.; McInerney, M.F. Dysregulated Toll-like receptor expression and signaling in bone marrow-derived macrophages at the onset of diabetes in the non-obese diabetic mouse. Int. Immunol. 2006, 18, 1101-1113. [CrossRef] [PubMed]

64. Devaraj, S.; Dasu, M.R.; Park, S.H.; Jialal, I. Increased levels of ligands of Toll-like receptors 2 and 4 in type 1 diabetes. Diabetologia 2009, 52, 1665-1668. [CrossRef] [PubMed]

65. Schmidt, H.; Hansen, G.; Singh, S.; Hanuszkiewicz, A.; Lindner, B.; Fukase, K.; Woodard, R.; Holst, O.; Hilgenfeld, R.; Mamat, U.; et al. Structural and mechanistic analysis of the membrane-embedded glycosyltransferase WaaA required for lipopolysaccharide synthesis. Proc. Natl. Acad. Sci. USA 2012, 109, 6253-6258. [CrossRef] [PubMed]

66. Demirci, M.; Tokman, H.B.; Taner, Z.; Keskin, F.E.; Çağatay, P.; Bakar, Y.O.; Özyazar, M.; Kiraz, N.; Kocazeybek, B.S. Bacteroidetes and Firmicutes levels in gut microbiota and effects of hosts TLR2/TLR4 gene expression levels in adult type 1 diabetes patients in Istanbul, Turkey. J. Diabetes Complicat. 2019, 34, 107449. [CrossRef]

67. Huang, Y.; Li, S.-C.; Hu, J.; Ruan, H.-B.; Guo, H.-M.; Zhang, H.-H.; Wang, X.; Pei, Y.-F.; Pan, Y.; Fang, C. Gut microbiota profiling in Han Chinese with type 1 diabetes. Diabetes Res. Clin. Pract. 2018, 141, 256-263. [CrossRef]

68. Murri, M.; Leiva, I.; Gomez-Zumaquero, J.M.; Tinahones, F.J.; Cardona, F.; Soriguer, F.; Queipo-Ortuño, M.I. Gut microbiota in children with type 1 diabetes differs from that in healthy children: A case-control study. BMC Med. 2013, 11, 46. [CrossRef]

69. Brown, C.T.; Davis-Richardson, A.G.; Giongo, A.; Gano, K.A.; Crabb, D.B.; Mukherjee, N.; Casella, G.; Drew, J.; Ilonen, J.; Knip, M.; et al. Gut Microbiome Metagenomics Analysis Suggests a Functional Model for the Development of Autoimmunity for Type 1 Diabetes. PLoS ONE 2011, 6, e25792. [CrossRef]

70. Giongo, A.; Gano, K.A.; Crabb, D.B.; Mukherjee, N.; Novelo, L.L.; Casella, G.; Drew, J.C.; Ilonen, J.; Knip, M.; Hyoty, H.; et al. Toward defining the autoimmune microbiome for type 1 diabetes. ISME J. 2010, 5, 82-91. [CrossRef]

71. Higuchi, B.S.; Rodrigues, N.; Gonzaga, M.I.; Paiolo, J.C.C.; Stefanutto, N.; Omori, W.P.; Pinheiro, D.G.; Brisotti, J.L.; Matheucci, E.J.; Mariano, V.S.; et al. Intestinal Dysbiosis in Autoimmune Diabetes Is Correlated with Poor Glycemic Control and Increased Interleukin-6: A Pilot Study. Front. Immunol. 2018, 9, 1689. [CrossRef]

72. Leiva-Gea, I.; Sánchez-Alcoholado, L.; Martín-Tejedor, B.; Castellano-Castillo, D.; Moreno-Indias, I.; Urda-Cardona, A.; Tinahones, F.J.; Fernández-García, J.C.; Queipo-Ortuño, M.I. Gut Microbiota Differs in Composition and Functionality Between Children with Type 1 Diabetes and MODY2 and Healthy Control Subjects: A Case-Control Study. Diabetes Care 2018, 41, 2385-2395. [CrossRef]

73. Pellegrini, S.; Sordi, V.; Bolla, A.M.; Saita, D.; Ferrarese, R.; Canducci, F.; Clementi, M.; Invernizzi, F.; Mariani, A.; Bonfanti, R.; et al. Duodenal Mucosa of Patients with Type 1 Diabetes Shows Distinctive Inflammatory Profile and Microbiota. J. Clin. Endocrinol. Metab. 2017, 102, 1468-1477. [CrossRef] [PubMed] 
74. $\mathrm{Wu}, \mathrm{Y}$; Y You, Q.; Fei, J.; Wu, J. Changes in the gut microbiota: A possible factor influencing peripheral blood immune indexes in non-obese diabetic mice. Antonie Van Leeuwenhoek 2021, 1-14. [CrossRef]

75. Ma, Q.; Li, Y.; Wang, J.; Li, P.; Duan, Y.; Dai, H.; An, Y.; Cheng, L.; Wang, T.; Wang, C.; et al. Investigation of gut microbiome changes in type 1 diabetic mellitus rats based on high-throughput sequencing. Biomed. Pharmacother. 2020, 124, 109873. [CrossRef] [PubMed]

76. Prasad, R.; Duan, Y.; Floyd, J.L.; Grant, M.B. 48-OR: Gut Dysbiosis Promotes Diabetic Retinopathy (DR) through TLR-2 Activation by Peptidoglycan (PGN) in Angiotensin Converting Enzyme 2 (ACE2) Deficient Type 1 Diabetic (T1D) Mice. Diabetes 2019, 68, 48. [CrossRef]

77. Patterson, E.; Marques, T.M.; O’Sullivan, O.; Fitzgerald, P.; Fitzgerald, G.F.; Cotter, P.; Dinan, T.; Cryan, J.; Stanton, C.; Ross, R. Streptozotocin-induced type-1-diabetes disease onset in Sprague-Dawley rats is associated with an altered intestinal microbiota composition and decreased diversity. Microbiology 2015, 161, 182-193. [CrossRef]

78. Hara, N.; Alkanani, A.K.; Ir, D.; Robertson, C.E.; Wagner, B.D.; Frank, D.N.; Zipris, D. Prevention of Virus-Induced Type 1 Diabetes with Antibiotic Therapy. J. Immunol. 2012, 189, 3805. [CrossRef]

79. Roesch, L.; Lorca, G.L.; Casella, G.; Giongo, A.; Naranjo, A.; Pionzio, A.M.; Li, N.; Mai, V.; Wasserfall, C.; Schatz, D.; et al. Culture-independent identification of gut bacteria correlated with the onset of diabetes in a rat model. ISME J. 2009, 3, 536-548. [CrossRef] [PubMed]

80. Brugman, S.; Klatter, F.A.; Visser, J.T.J.; Wildeboer-Veloo, A.C.M.; Harmsen, H.J.M.; Rozing, J.; Bos, N.A. Antibiotic treatment partially protects against type 1 diabetes in the Bio-Breeding diabetes-prone rat. Is the gut flora involved in the development of type 1 diabetes? Diabetologia 2006, 49, 2105-2108. [CrossRef] [PubMed]

81. Gürsoy, S.; Koçkar, T.; Atik, S.U.; Önal, Z.; Önal, H.; Adal, E. Autoimmunity and intestinal colonization by Candida albicans in patients with type 1 diabetes at the time of the diagnosis. Korean J. Pediatr. 2018, 61, 217-220. [CrossRef] [PubMed]

82. Pinto, E.; Anselmo, M.; Calha, M.; Bottrill, A.; Duarte, G.I.D.S.; Andrew, P.W.; Faleiro, M.L. The intestinal proteome of diabetic and control children is enriched with different microbial and host proteins. Microbiology 2017, 163, 161-174. [CrossRef] [PubMed]

83. de Goffau, M.C.; Fuentes, S.; van den Bogert, B.; Honkanen, H.; de Vos, W.M.; Welling, G.W.; Hyöty, H.; Harmsen, H.J. Aberrant gut microbiota composition at the onset of type 1 diabetes in young children. Diabetologia 2014, 57, 1569-1577. [CrossRef] [PubMed]

84. Soyucen, E.; Gulcan, A.; Aktuglu-Zeybek, A.C.; Onal, H.; KIYKIM, E.; Aydin, A. Differences in the gut microbiota of healthy children and those with type 1 diabetes. Pediatr. Int. 2014, 56, 336-343. [CrossRef]

85. Kesh, K.; Mendez, R.; Abdelrahman, L.; Banerjee, S.; Banerjee, S. Type 2 diabetes induced microbiome dysbiosis is associated with therapy resistance in pancreatic adenocarcinoma. Microb. Cell Factories 2020, 19, 1-14. [CrossRef] [PubMed]

86. Yin, R.; Xue, Y.; Hu, J.; Hu, X.; Shen, Q. The effects of diet and streptozotocin on metabolism and gut microbiota in a type 2 diabetes mellitus mouse model. Food Agric. Immunol. 2020, 31, 723-739. [CrossRef]

87. Grasset, E.; Puel, A.; Charpentier, J.; Collet, X.; Christensen, J.E.; Tercé, F.; Burcelin, R. A Specific Gut Microbiota Dysbiosis of Type 2 Diabetic Mice Induces GLP-1 Resistance through an Enteric NO-Dependent and Gut-Brain Axis Mechanism. Cell Metab. 2017, 26, 278. [CrossRef]

88. Everard, A.; Belzer, C.; Geurts, L.; Ouwerkerk, J.P.; Druart, C.; Bindels, L.B.; Guiot, Y.; Derrien, M.; Muccioli, G.G.; Delzenne, N.M.; et al. Cross-talk between Akkermansia muciniphila and intestinal epithelium controls diet-induced obesity. Proc. Natl. Acad. Sci. USA 2013, 110, 9066. [CrossRef] [PubMed]

89. Li, Q.; Chang, Y.; Zhang, K.; Chen, H.; Tao, S.; Zhang, Z. Implication of the gut microbiome composition of type 2 diabetic patients from northern China. Sci. Rep. 2020, 10, 5450. [CrossRef] [PubMed]

90. Chávez-Carbajal, A.; Pizano-Zárate, M.L.; Hernández-Quiroz, F.; Ortiz-Luna, G.F.; Morales-Hernández, R.M.; De Sales-Millán, A.; Hernández-Trejo, M.; García-Vite, A.; Beltrán-Lagunes, L.; Hoyo-Vadillo, C.; et al. Characterization of the Gut Microbiota of Individuals at Different T2D Stages Reveals a Complex Relationship with the Host. Microorganisms 2020, 8, 94. [CrossRef]

91. Doumatey, A.P.; Adeyemo, A.; Zhou, J.; Lei, L.; Adebamowo, S.N.; Adebamowo, C.; Rotimi, C.N. Gut Microbiome Profiles Are Associated With Type 2 Diabetes in Urban Africans. Front. Cell. Infect. Microbiol. 2020, 10, 63. [CrossRef]

92. Sedighi, M.; Razavi, S.; Navab-Moghadam, F.; Khamseh, M.E.; Alaei-Shahmiri, F.; Mehrtash, A.; Amirmozafari, N. Comparison of gut microbiota in adult patients with type 2 diabetes and healthy individuals. Microb. Pathog. 2017, 111, 362-369. [CrossRef]

93. Inoue, R.; Ohue-Kitano, R.; Tsukahara, T.; Tanaka, M.; Masuda, S.; Inoue, T.; Yamakage, H.; Kusakabe, T.; Hasegawa, K.; Shimatsu, A.; et al. Prediction of functional profiles of gut microbiota from 16S rRNA metagenomic data provides a more robust evaluation of gut dysbiosis occurring in Japanese type 2 diabetic patients. J. Clin. Biochem. Nutr. 2017, 61, 217-221. [CrossRef]

94. Wu, X.; Ma, C.; Han, L.; Nawaz, M.; Gao, F.; Zhang, X.; Yu, P.; Zhao, C.; Li, L.; Zhou, A.; et al. Molecular Characterisation of the Faecal Microbiota in Patients with Type II Diabetes. Curr. Microbiol. 2010, 61, 69-78. [CrossRef]

95. Larsen, N.; Vogensen, F.; Berg, F.V.D.; Nielsen, D.S.; Andreasen, A.S.; Pedersen, B.K.; Abu Al-Soud, W.; Sørensen, S.; Hansen, L.H.; Jakobsen, M. Gut Microbiota in Human Adults with Type 2 Diabetes Differs from Non-Diabetic Adults. PLoS ONE 2010, 5, e9085. [CrossRef] [PubMed]

96. Bilen, H.; Ates, O.; Astam, N.; Uslu, H.; Akcay, G.; Baykal, O. Conjunctival flora in patients with type 1 or type 2 diabetes mellitus. Adv. Ther. 2007, 24, 1028-1035. [CrossRef] [PubMed]

97. Kim, Y.A.; Keogh, J.; Clifton, P.M. Probiotics, prebiotics, synbiotics and insulin sensitivity. Nutr. Res. Rev. 2017, 31, 35-51. [CrossRef] [PubMed] 
98. Dao, M.C.; Everard, A.; Aron-Wisnewsky, J.; Sokolovska, N.; Prifti, E.; Verger, E.O.; Kayser, B.D.; Levenez, F.; Chilloux, J.; Hoyles, L.; et al. Akkermansia muciniphila and improved metabolic health during a dietary intervention in obesity: Relationship with gut microbiome richness and ecology. Gut 2016, 65, 426-436. [CrossRef]

99. Moroti, C.; Magri, L.F.S.; Costa, M.D.R.; Cavallini, D.C.; Sivieri, K. Effect of the consumption of a new symbiotic shake on glycemia and cholesterol levels in elderly people with type 2 diabetes mellitus. Lipids Heal. Dis. 2012, 11, 1-8. [CrossRef]

100. Zhang, Y.; Zhang, H. Microbiota associated with type 2 diabetes and its related complications. Food Sci. Hum. Wellness 2013, 2, 167-172. [CrossRef]

101. Katsimichas, T.; Antonopoulos, A.; Katsimichas, A.; Ohtani, T.; Sakata, Y.; Tousoulis, D. The intestinal microbiota and cardiovascular disease. Cardiovasc. Res. 2019, 115, 1471-1486. [CrossRef]

102. Hildebrandt, M.A.; Hoffmann, C.; Sherrill-Mix, S.A.; Keilbaugh, S.A.; Hamady, M.; Chen, Y.; Knight, R.; Ahima, R.S.; Bushman, F.; $\mathrm{Wu}, \mathrm{G} . \mathrm{D}$. High-Fat Diet Determines the Composition of the Murine Gut Microbiome Independently of Obesity. Gastroenterology 2009, 137, 1716-1724.e2. [CrossRef] [PubMed]

103. Sang, T.; Guo, C.; Guo, D.; Wu, J.; Wang, Y.; Wang, Y.; Chen, J.; Chen, C.; Wu, K.; Na, K.; et al. Suppression of obesity and inflammation by polysaccharide from sporoderm-broken spore of Ganoderma lucidum via gut microbiota regulation. Carbohydr. Polym. 2021, 256, 117594. [CrossRef]

104. Beckmann, L.; Künstner, A.; Freschi, M.L.; Huber, G.; Stölting, I.; Ibrahim, S.M.; Hirose, M.; Freitag, M.; Langan, E.A.; Matschl, U.; et al. Telmisartan induces a specific gut microbiota signature which may mediate its antiobesity effect. Pharmacol. Res. 2021, 170, 105724. [CrossRef]

105. Bagarolli, R.A.; Tobar, N.; Oliveira, A.; Araújo, T.; Carvalho, B.; Rocha, G.; Vecina, J.F.; Calisto, K.; Guadagnini, D.; Prada, P.D.O.; et al. Probiotics modulate gut microbiota and improve insulin sensitivity in DIO mice. J. Nutr. Biochem. 2017, 50, 16-25. [CrossRef] [PubMed]

106. Lam, Y.Y.; Ha, C.W.Y.; Campbell, C.; Mitchell, A.; Dinudom, A.; Oscarsson, J.; Cook, D.I.; Hunt, N.H.; Caterson, I.D.; Holmes, A.J.; et al. Increased Gut Permeability and Microbiota Change Associate with Mesenteric Fat Inflammation and Metabolic Dysfunction in Diet-Induced Obese Mice. PLoS ONE 2012, 7, e34233. [CrossRef] [PubMed]

107. Turnbaugh, P.; Ley, R.; Mahowald, M.A.; Magrini, V.; Mardis, E.R.; Gordon, J.I. An obesity-associated gut microbiome with increased capacity for energy harvest. Nature 2006, 444, 1027-1031. [CrossRef] [PubMed]

108. Da Silva, C.C.; Monteil, M.A.; Davis, E.M. Overweight and Obesity in Children Are Associated with an Abundance of Firmicutes and Reduction of Bifidobacterium in Their Gastrointestinal Microbiota. Child. Obes. 2020, 16, 204-210. [CrossRef] [PubMed]

109. Gao, R.; Zhu, C.; Li, H.; Yin, M.; Pan, C.; Huang, L.; Kong, C.; Wang, X.; Zhang, Y.; Qu, S.; et al. Dysbiosis Signatures of Gut Microbiota Along the Sequence from Healthy, Young Patients to Those with Overweight and Obesity. Obesity 2017, 26, 351-361. [CrossRef] [PubMed]

110. Kalliomäki, M.; Collado, M.C.; Salminen, S.; Isolauri, E. Early differences in fecal microbiota composition in children may predict overweight. Am. J. Clin. Nutr. 2008, 87, 534-538. [CrossRef]

111. Collado, M.C.; Isolauri, E.; Laitinen, K.; Salminen, S. Distinct composition of gut microbiota during pregnancy in overweight and normal-weight women. Am. J. Clin. Nutr. 2008, 88, 894-899. [CrossRef] [PubMed]

112. Bäckhed, F.; Ding, H.; Wang, T.; Hooper, L.V.; Koh, G.Y.; Nagy, A.; Semenkovich, C.F.; Gordon, J.I. The gut microbiota as an environmental factor that regulates fat storage. Proc. Natl. Acad. Sci. USA 2004, 101, 15718-15723. [CrossRef] [PubMed]

113. Asehnoune, K.; Strassheim, D.; Mitra, S.; Kim, J.Y.; Abraham, E. Involvement of Reactive Oxygen Species in Toll-Like Receptor 4-Dependent Activation of NF-KB. J. Immunol. 2004, 172, 2522-2529. [CrossRef] [PubMed]

114. Lu, Y.-C.; Yeh, W.-C.; Ohashi, P.S. LPS/TLR4 signal transduction pathway. Cytokine 2008, 42, 145-151. [CrossRef] [PubMed]

115. Boutagy, N.E.; McMillan, R.P.; Frisard, M.I.; Hulver, M.W. Metabolic endotoxemia with obesity: Is it real and is it relevant? Biochimie 2016, 124, 11-20. [CrossRef]

116. Kersten, S.; Mandard, S.; Tan, N.S.; Escher, P.; Metzger, D.; Chambon, P.; Gonzalez, F.J.; Desvergne, B.; Wahli, W. Characterization of the Fasting-induced Adipose Factor FIAF, a Novel Peroxisome Proliferator-activated Receptor Target Gene. J. Biol. Chem. 2000, 275, 28488-28493. [CrossRef]

117. Cushing, E.M.; Chi, X.; Sylvers, K.L.; Shetty, S.K.; Potthoff, M.; Davies, B.S. Angiopoietin-like 4 directs uptake of dietary fat away from adipose during fasting. Mol. Metab. 2017, 6, 809-818. [CrossRef]

118. Bäckhed, F.; Manchester, J.K.; Semenkovich, C.; Gordon, J.I. Mechanisms underlying the resistance to diet-induced obesity in germ-free mice. Proc. Natl. Acad. Sci. USA 2007, 104, 979-984. [CrossRef]

119. Zhi, C.; Huang, J.; Wang, J.; Cao, H.; Bai, Y.; Guo, J.; Su, Z. Connection between gut microbiome and the development of obesity. Eur. J. Clin. Microbiol. Infect. Dis. 2019, 38, 1987-1998. [CrossRef]

120. Lee, P.; Yacyshyn, B.R.; Yacyshyn, M.B. Gut microbiota and obesity: An opportunity to alter obesity through faecal microbiota transplant (FMT). Diabetes Obes. Metab. 2018, 21, 479-490. [CrossRef]

121. Pascale, A.; Marchesi, N.; Govoni, S.; Coppola, A.; Gazzaruso, C. THE role of gut microbiota in obesity, diabetes mellitus and effect of metformin: New insights into old diseases. Curr. Opin. Pharmacol. 2019, 49, 1-5. [CrossRef]

122. Arora, T.; Sharma, R.; Frost, G. Propionate. Anti-obesity and satiety enhancing factor? Appetite 2011, 56, 511-515. [CrossRef]

123. Kimura, I.; Ozawa, K.; Inoue, D.; Imamura, T.; Kimura, K.; Maeda, T.; Terasawa, K.; Kashihara, D.; Hirano, K.; Tani, T.; et al. The gut microbiota suppresses insulin-mediated fat accumulation via the short-chain fatty acid receptor GPR43. Nat. Commun. 2013, 4, 1829. [CrossRef] [PubMed] 
124. Virtue, A.T.; McCright, S.J.; Wright, J.M.; Jimenez, M.T.; Mowel, W.K.; Kotzin, J.J.; Joannas, L.; Basavappa, M.G.; Spencer, S.P.; Clark, M.L.; et al. The gut microbiota regulates white adipose tissue inflammation and obesity via a family of microRNAs. Sci. Transl. Med. 2019, 11, eaav1892. [CrossRef] [PubMed]

125. Guldris, S.C.; Parra, E.G.; Amenós, A.C. Cases Amenós, Gut microbiota in chronic kidney disease. Nefrología (Engl. Ed.) 2017, 37, 9-19. [CrossRef]

126. Felizardo, R.; Castoldi, A.; Andrade-Oliveira, V.; Câmara, N.O.S. The microbiota and chronic kidney diseases: A double-edged sword. Clin. Transl. Immunol. 2016, 5, e86. [CrossRef] [PubMed]

127. Valcheva, R.; Hotte, N.; Gillevet, P.; Sikaroodi, M.; Thiessen, A.; Madsen, K.L. Soluble Dextrin Fibers Alter the Intestinal Microbiota and Reduce Proinflammatory Cytokine Secretion in Male IL-10-Deficient Mice. J. Nutr. 2015, 145, 2060-2066. [CrossRef]

128. Neelofar, K.; Arif, Z.; Arafat, M.Y.; Alam, K.; Ahmad, J. A study on correlation between oxidative stress parameters and inflammatory markers in type 2 diabetic patients with kidney dysfunction in north Indian population. J. Cell. Biochem. 2018, 120, 4892-4902. [CrossRef]

129. Mafra, D.; Lobo, J.C.; Barros, A.F.; Koppe, L.; Vaziri, N.D.; Fouque, D. Role of altered intestinal microbiota in systemic inflammation and cardiovascular disease in chronic kidney disease. Futur. Microbiol. 2014, 9, 399-410. [CrossRef]

130. Sabatino, A.; Regolisti, G.; Brusasco, I.; Cabassi, A.; Morabito, S.; Fiaccadori, E. Alterations of intestinal barrier and microbiota in chronic kidney disease. Nephrol. Dial. Transplant. 2014, 30, 924-933. [CrossRef]

131. Nishiyama, K.; Aono, K.; Fujimoto, Y.; Kuwamura, M.; Okada, T.; Tokumoto, H.; Izawa, T.; Okano, R.; Nakajima, H.; Takeuchi, T.; et al. Chronic kidney disease after 5/6 nephrectomy disturbs the intestinal microbiota and alters intestinal motility. J. Cell Physiol. 2019, 234, 6667-6678. [CrossRef]

132. Yang, J.; Li, Q.; Henning, S.M.; Zhong, J.; Hsu, M.; Lee, R.; Long, J.; Chan, B.; Nagami, G.T.; Heber, D.; et al. Effects of Prebiotic Fiber Xylooligosaccharide in Adenine-Induced Nephropathy in Mice. Mol. Nutr. Food Res. 2018, 62, e1800014. [CrossRef]

133. Yang, T.; Santisteban, M.; Rodriguez, V.; Vermali, R.; Ahmari, N.; Carvajal, J.M.; Zadeh, M.; Gong, M.; Qi, Y.; Zubcevic, J.; et al. Gut Dysbiosis Is Linked to Hypertension. Hypertension 2015, 65, 1331-1340. [CrossRef] [PubMed]

134. Vaziri, N.D.; Wong, J.; Pahl, M.; Piceno, Y.; Yuan, J.; DeSantis, T.Z.; Ni, Z.; Nguyen, T.-H.; Andersen, G. Chronic kidney disease alters intestinal microbial flora. Kidney Int. 2013, 83, 308-315. [CrossRef] [PubMed]

135. Tanida, M.; Yamano, T.; Maeda, K.; Okumura, N.; Fukushima, Y.; Nagai, K. Effects of intraduodenal injection of Lactobacillus johnsonii La1 on renal sympathetic nerve activity and blood pressure in urethane-anesthetized rats. Neurosci. Lett. 2005, 389, 109-114. [CrossRef] [PubMed]

136. Kawase, M.; Hashimoto, H.; Hosoda, M.; Morita, H.; Hosono, A. Effect of Administration of Fermented Milk Containing Whey Protein Concentrate to Rats and Healthy Men on Serum Lipids and Blood Pressure. J. Dairy Sci. 2000, 83, 255-263. [CrossRef]

137. Vallianou, N.G.; Geladari, E.; Kounatidis, D. Microbiome and hypertension: Where are we now? J. Cardiovasc. Med. 2020, 21, 83-88. [CrossRef]

138. Sampaio-Maia, B.; Simões-Silva, L.; Pestana, M.; Araujo, R.; Soares-Silva, I.J. Chapter Three-The Role of the Gut Microbiome on Chronic Kidney Disease. In Advances in Applied Microbiology; Sima, S., Geoffrey, M.G., Eds.; Academic Press: Cambridge, MA, USA, 2016; pp. 65-94.

139. Roncal, C.; Martínez-Aguilar, E.; Orbe, J.; Ravassa, S.; Fernandez-Montero, A.; Saenz-Pipaon, G.; Ugarte, A.; De Mendoza, A.E.-H.; Rodriguez, J.A.; Fernández-Alonso, S.; et al. Trimethylamine-N-Oxide (TMAO) Predicts Cardiovascular Mortality in Peripheral Artery Disease. Sci. Rep. 2019, 9, 15580. [CrossRef] [PubMed]

140. Jiang, S.; Xie, S.; Lv, D.; Zhang, Y.; Deng, J.; Zeng, L.; Chen, Y. A reduction in the butyrate producing species Roseburia spand Faecalibacterium prausnitzii is associated with chronic kidney disease progression. Antonie Van Leeuwenhoek 2016, 109, 1389-1396. [CrossRef]

141. Ranganathan, N.; Friedman, E.A.; Tam, P.; Rao, V.; Ranganathan, P.; Dheer, R. Probiotic dietary supplementation in patients with stage 3 and 4 chronic kidney disease: A 6-month pilot scale trial in Canada. Curr. Med Res. Opin. 2009, 25, 1919-1930. [CrossRef]

142. Fukuuchi, F.; Hida, M.; Aiba, Y.; Koga, Y.; Endoh, M.; Kurokawa, K.; Sakai, H. Intestinal bacteria-derived putrefactants in chronic renal failure. Clin. Exp. Nephrol. 2002, 6, 99-104. [CrossRef]

143. Hida, M.; Aiba, Y.; Sawamura, S.; Suzuki, N.; Satoh, T.; Koga, Y. Inhibition of the Accumulation of Uremic Toxins in the Blood and Their Precursors in the Feces after Oral Administration of Lebenin ${ }^{\circledR}$, a Lactic Acid Bacteria Preparation, to Uremic Patients Undergoing Hemodialysis. Nephron 1996, 74, 349-355. [CrossRef]

144. Jiang, S.; Xie, S.; Lv, D.; Wang, P.; He, H.; Zhang, T.; Zhou, Y.; Lin, Q.; Zhou, H.; Jiang, J.; et al. Alteration of the gut microbiota in Chinese population with chronic kidney disease. Sci. Rep. 2017, 7, 2870. [CrossRef] [PubMed]

145. Crespo-Salgado, J.; Vehaskari, V.M.; Stewart, T.; Ferris, M.; Zhang, Q.; Wang, G.; Blanchard, E.E.; Taylor, C.M.; Kallash, M.; Greenbaum, L.A.; et al. Intestinal microbiota in pediatric patients with end stage renal disease: A Midwest Pediatric Nephrology Consortium study. Microbiome 2016, 4, 50. [CrossRef] [PubMed]

146. Wong, J.; Piceno, Y.; DeSantis, T.Z.; Pahl, M.; Andersen, G.; Vaziri, N.D. Expansion of Urease- and Uricase-Containing, Indoleand p-Cresol-Forming and Contraction of Short-Chain Fatty Acid-Producing Intestinal Microbiota in ESRD. Am. J. Nephrol. 2014, 39, 230-237. [CrossRef]

147. Wang, I.-K.; Lai, H.-C.; Yu, C.-J.; Liang, C.-C.; Chang, C.-T.; Kuo, H.-L.; Yang, Y.-F.; Lin, C.-C.; Lin, H.-H.; Liu, Y.-L.; et al. Real-Time PCR Analysis of the Intestinal Microbiotas in Peritoneal Dialysis Patients. Appl. Environ. Microbiol. 2012, 78, 1107-1112. [CrossRef] [PubMed] 
148. Wang, F.; Jiang, H.; Shi, K.; Ren, Y.; Zhang, P.; Cheng, S. Gut bacterial translocation is associated with microinflammation in end-stage renal disease patients. Nephrology 2012, 17, 733-738. [CrossRef]

149. Tang, Y.; Chen, Y.; Jiang, H.; Nie, D. Short-chain fatty acids induced autophagy serves as an adaptive strategy for retarding mitochondria-mediated apoptotic cell death. Cell Death Differ. 2010, 18, 602-618. [CrossRef]

150. Andrade-Oliveira, V.; Amano, M.; Correa-Costa, M.; Castoldi, A.; Felizardo, R.; De Almeida, D.C.; Bassi, J.; Vieira, P.; Hiyane, M.I.; Rodas, A.C.; et al. Gut Bacteria Products Prevent AKI Induced by Ischemia-Reperfusion. J. Am. Soc. Nephrol. 2015, 26, 1877-1888. [CrossRef]

151. Yong, R.; Chen, X.-M.; Shen, S.; Vijayaraj, S.; Ma, Q.; Pollock, C.A.; Saad, S. Plumbagin Ameliorates Diabetic Nephropathy via Interruption of Pathways that Include NOX4 Signalling. PLoS ONE 2013, 8, e73428. [CrossRef] [PubMed]

152. Huang, C.; Lin, M.Z.; Cheng, D.; Braet, F.; Pollock, C.A.; Chen, X.-M. Thioredoxin-interacting protein mediates dysfunction of tubular autophagy in diabetic kidneys through inhibiting autophagic flux. Lab. Investig. 2014, 94, 309-320. [CrossRef] [PubMed]

153. Stangenberg, S.; Nguyen, L.T.; Chen, H.; Al-Odat, I.; Killingsworth, M.C.; Gosnell, M.E.; Anwer, A.G.; Goldys, E.M.; Pollock, C.A.; Saad, S. Oxidative stress, mitochondrial perturbations and fetal programming of renal disease induced by maternal smoking. Int. J. Biochem. Cell Biol. 2015, 64, 81-90. [CrossRef]

154. Gurukar, M.S.A.; Mahadevamma, S.; Chilkunda, N.D. Renoprotective Effect ofCoccinia indicaFruits and Leaves in Experimentally Induced Diabetic Rats. J. Med. Food 2013, 16, 839-846. [CrossRef]

155. Pluznick, J. A novel SCFA receptor, the microbiota, and blood pressure regulation. Gut Microbes 2014, 5, 202-207. [CrossRef]

156. Natarajan, N.; Pluznick, J.L. Olfaction in the kidney: 'smelling' gut microbial metabolites. Exp. Physiol. 2016, 101, 478-481. [CrossRef]

157. Agarwal, A.; Jadhav, P.; Deshmukh, Y. Prescribing pattern and efficacy of anti-diabetic drugs in maintaining optimal glycemic levels in diabetic patients. J. Basic Clin. Pharm. 2014, 5, 79-83. [CrossRef]

158. Durgan, D.J.; Ganesh, B.; Cope, J.L.; Ajami, N.J.; Phillips, S.C.; Petrosino, J.F.; Hollister, E.B.; Bryan, J.R.M. Role of the Gut Microbiome in Obstructive Sleep Apnea-Induced Hypertension. Hypertension 2016, 67, 469-474. [CrossRef] [PubMed]

159. Vergès, B.; Bonnard, C.; Renard, E. Beyond glucose lowering: Glucagon-like peptide-1 receptor agonists, body weight and the cardiovascular system. Diabetes Metab. 2011, 37, 477-488. [CrossRef]

160. Nagahisa, T.; Saisho, Y. Cardiorenal Protection: Potential of SGLT2 Inhibitors and GLP-1 Receptor Agonists in the Treatment of Type 2 Diabetes. Diabetes Ther. 2019, 10, 1733-1752. [CrossRef] [PubMed]

161. Perkovic, V.; Jardine, M.J.; Neal, B.; Bompoint, S.; Heerspink, H.J.; Charytan, D.; Edwards, R.; Agarwal, R.; Bakris, G.; Bull, S.; et al. Canagliflozin and Renal Outcomes in Type 2 Diabetes and Nephropathy. N. Engl. J. Med. 2019, 380, 2295-2306. [CrossRef]

162. Wheeler, D.C.; Stefansson, B.V.; Batiushin, M.; Bilchenko, O.; Cherney, D.Z.I.; Chertow, G.M.; Douthat, W.; Dwyer, J.P.; Escudero, E.; Pecoits-Filho, R.; et al. The dapagliflozin and prevention of adverse outcomes in chronic kidney disease (DAPA-CKD) trial: Baseline characteristics. Nephrol. Dial. Transplant. 2020, 35, 1700-1711. [CrossRef] [PubMed]

163. Tonucci, L.B.; dos Santos, K.M.O.; de Oliveira, L.L.; Ribeiro, S.M.R.; Martino, H.S.D. Clinical application of probiotics in type 2 diabetes mellitus: A randomized, double-blind, placebo-controlled study. Clin. Nutr. 2017, 36, 85-92. [CrossRef] [PubMed]

164. Ghaisas, S.; Maher, J.; Kanthasamy, A. Gut microbiome in health and disease: Linking the microbiome-gut-brain axis and environmental factors in the pathogenesis of systemic and neurodegenerative diseases. Pharmacol. Ther. 2015, 158, 52-62. [CrossRef]

165. Klosterbuer, A.; Roughead, Z.F.; Slavin, J. Benefits of Dietary Fiber in Clinical Nutrition. Nutr. Clin. Pract. 2011, 26, 625-635. [CrossRef] [PubMed]

166. Padayachee, A.; Netzel, G.; Netzel, M.; Day, L.; Zabaras, D.; Mikkelsen, D.; Gidley, M. Binding of polyphenols to plant cell wall analogues-Part 2: Phenolic acids. Food Chem. 2012, 135, 2287-2292. [CrossRef] [PubMed]

167. Holt, S.; Jong, V.D.; Faramus, E.; Lang, T.; Brand Miller, J. A bioflavonoid in sugar cane can reduce the postprandial glycaemic response to a high-GI starchy food. Asia Pac. J. Clin. Nutr. 2003, 12, s66.

168. Palafox-Carlos, H.; Zavala, J.F.A.; González-Aguilar, G.A. The Role of Dietary Fiber in the Bioaccessibility and Bioavailability of Fruit and Vegetable Antioxidants. J. Food Sci. 2011, 76, R6-R15. [CrossRef]

169. Slavin, J.L.; Lloyd, B. Health Benefits of Fruits and Vegetables. Adv. Nutr. 2012, 3, 506-516. [CrossRef]

170. Zoumpopoulou, G.; Pot, B.; Tsakalidou, E.; Papadimitriou, K. Dairy probiotics: Beyond the role of promoting gut and immune health. Int. Dairy J. 2017, 67, 46-60. [CrossRef]

171. Wanchai, K.; Pongchaidecha, A.; Chatsudthipong, V.; Chattipakorn, S.C.; Chattipakorn, N.; Lungkaphin, A. Role of Gastrointestinal Microbiota on Kidney Injury and the Obese Condition. Am. J. Med Sci. 2016, 353, 59-69. [CrossRef]

172. Arnold, J.W.; Roach, J.; Azcarate-Peril, M.A. Emerging Technologies for Gut Microbiome Research. Trends Microbiol. 2016, 24, 887-901. [CrossRef]

173. Hasegawa, S.; Jao, T.-M.; Inagi, R. Dietary Metabolites and Chronic Kidney Disease. Nutrients 2017, 9, 358. [CrossRef]

174. Cani, P.D.; Osto, M.; Geurts, L.; Everard, A. Involvement of gut microbiota in the development of low-grade inflammation and type 2 diabetes associated with obesity. Gut Microbes 2012, 3, 279-288. [CrossRef]

175. Han, X.; Lee, A.; Huang, S.; Gao, J.; Spence, J.R.; Owyang, C. Lactobacillus rhamnosus GG prevents epithelial barrier dysfunction induced by interferon-gamma and fecal supernatants from irritable bowel syndrome patients in human intestinal enteroids and colonoids. Gut Microbes 2018, 10, 59-76. [CrossRef] [PubMed] 
176. Ejtahed, H.S.; Mohtadi-Nia, J.; Homayouni-Rad, A.; Niafar, M.; Jafarabadi, M.A.; Mofid, V. Probiotic yogurt improves antioxidant status in type 2 diabetic patients. Nutrition 2012, 28, 539-543. [CrossRef] [PubMed]

177. Zou, J.; Chassaing, B.; Singh, V.; Pellizzon, M.; Ricci, M.; Fythe, M.D.; Kumar, M.V.; Gewirtz, A.T. Fiber-Mediated Nourishment of Gut Microbiota Protects against Diet-Induced Obesity by Restoring IL-22-Mediated Colonic Health. Cell Host Microbe 2017, 23, 41-53.e4. [CrossRef] [PubMed]

178. Zhang, Q.; Yu, H.; Xiao, X.; Hu, L.; Xin, F.; Yu, X. Inulin-type fructan improves diabetic phenotype and gut microbiota profiles in rats. Peer] 2018, 6, e4446. [CrossRef] [PubMed]

179. van der Beek, C.M.; Canfora, E.E.; Kip, A.M.; Gorissen, S.H.; Damink, S.W.; van Eijk, H.M.; Holst, J.J.; Blaak, E.E.; Dejong, C.H.; Lenaerts, K. The prebiotic inulin improves substrate metabolism and promotes short-chain fatty acid production in overweight to obese men. Metabolism 2018, 87, 25-35. [CrossRef]

180. Wang, J.; Tang, H.; Zhang, C.; Zhao, Y.; Derrien, M.; Rocher, E.; Vlieg, J.E.T.V.-H.; Strissel, K.J.; Zhao, L.; Obin, M.S.; et al. Modulation of gut microbiota during probiotic-mediated attenuation of metabolic syndrome in high fat diet-fed mice. ISME J. 2014, 9, 1-15. [CrossRef]

181. Million, M.; Angelakis, E.; Paul, M.; Armougom, F.; Leibovici, L.; Raoult, D. Comparative meta-analysis of the effect of Lactobacillus species on weight gain in humans and animals. Microb. Pathog. 2012, 53, 100-108. [CrossRef]

182. Million, M.; Maraninchi, M.; Henry, M.; Armougom, F.; Richet, H.; Carrieri, P.; Valero, R.; Raccah, D.; Vialettes, B.; Raoult, D. Obesity-associated gut microbiota is enriched in Lactobacillus reuteri and depleted in Bifidobacterium animalis and Methanobrevibacter smithii. Int. J. Obes. 2011, 36, 817-825. [CrossRef] [PubMed]

183. National Center for Complementary and Alternative Medicine. The Use of Complementary and Alternative Medicine in the United States; National Center for Complementary and Alternative Medicine: Bethesda, MD, USA, 2008.

184. Nahin, R.L.; Barnes, P.M.; Stussman, B.J. Expenditures on Complementary Health Approaches: United States, 2012. Natl. Health Stat. Rep. 2016, 95, 1-11.

185. Burke, K.; Lamont, J.T. Clostridium difficileInfection: A Worldwide Disease. Gut Liver 2014, 8, 1-6. [CrossRef] [PubMed]

186. Benech, N.; Leboucher, G.; Monard, C.; Ferry, T. Septic shock due to refractory severe clostridioides difficile colitis rapidly resolving after faecal microbiota transplantation. BMJ Case Rep. 2020, 13, e234329. [CrossRef]

187. Udayappan, S.D.; Hartstra, A.V.; Dallinga-Thie, G.; Nieuwdorp, M. Intestinal microbiota and faecal transplantation as treatment modality for insulin resistance and type 2 diabetes mellitus. Clin. ExImmunol. 2014, 177, 24-29. [CrossRef] [PubMed] 